\title{
Th17/Treg Imbalance in Murine Cystic Fibrosis Is Linked to Indoleamine 2,3-Dioxygenase Deficiency but Corrected by Kynurenines
}

\author{
Rossana G. Iannitti ${ }^{1}$, Agostinho Carvalho ${ }^{1,2,3}$, Cristina Cunha ${ }^{1}$, Antonella De Luca ${ }^{1}$, Gloria Giovannini ${ }^{1}$, \\ Andrea Casagrande1,4, Teresa Zelante ${ }^{1}$, Carmine Vacca', Francesca Fallarino', Paolo Puccetti', \\ Cristina Massi-Benedetti ${ }^{1}$, Gloria Defilippi ${ }^{5}$, Maria Russo5, Luigi Porcaro5, Carla Colombo ${ }^{5,6}$, \\ Luigi Ratclif7, Fernando M. De Benedictis ${ }^{8}$, and Luigina Romani ${ }^{1}$
}

\begin{abstract}
${ }^{1}$ Department of Experimental Medicine and Biochemical Sciences, University of Perugia, Perugia, Italy; ${ }^{2}$ Life and Health Sciences Research Institute (ICVS), School of Health Sciences, University of Minho, Braga, Portugal; ${ }^{3}$ ICVS/3B's-PT Government Associate Laboratory, Braga/Guimarães, Portugal; ${ }^{4}$ Istituto Superiore di Sanità, Rome, Italy; ${ }^{5}$ Fondazione IRCCS Cà Granda, Ospedale Maggiore Policlinico, Milan, Italy; ${ }^{6}$ University of Milan, Milan, Italy; ${ }^{7}$ Servizio di Supporto Fibrosi Cistica, Istituto Ospedale G. Tatarella, Cerignola, Foggia, Italy; and ${ }^{8}$ Department of Mother and Child Health, Salesi Children's Hospital, Ancona, Italy
\end{abstract}

Rationale: Mutations in the cystic fibrosis (CF) transmembrane conductance regulator affect the innate epithelial immune function of the lung, resulting in exaggerated and ineffective airway inflammation that fails to eradicate pathogenic fungi. The appreciation of whether such fungi are primarily responsible for or a consequence of ineffective airway inflammation is important for future therapeutics development.

Objectives: To characterize the impact of the tryptophan/kynurenine pathway on pathogenic airway inflammation preventing effective fungal clearance in CF.

Methods: We studied the expression of indoleamine 2,3-dioxygenase (IDO), the first enzyme in the kynurenine pathway of tryptophan degradation, in human and murine $C F$, the impact of IDO on lung inflammation and immunity in murine $\mathrm{CF}$, and the potential role of tryptophan catabolism in pathogenesis and therapy of fungusassociated lung inflammation.

Measurements and Main Results: IDO was defective in murine and human CF. Genetic and transcriptional regulatory mechanisms contributed to dysfunctional IDO activity that, in turn, correlated with imbalanced Th17/Treg-cell responses to Aspergillus fumigatus in murine CF. Treatments enhancing IDO function or preventing pathogenic Th17-cell activation restored protective immunity to the fungus and improved lung inflammation in murine CF.

(Received in original form July 31, 2012; accepted in final form November 20, 2012)

Supported by a grant from the Italian Cystic Fibrosis Research Foundation (Research Project no. FFC\#21/2010 to L. Romani) with the contribution of Francesca Guadagnin, Coca Cola Light Tribute to Fashion, and Delegazione FFC di Belluno; and the Specific Targeted Research Project "ALLFUN" (FP7-HEALTH-2009 contract no. 260338 to L. Romani). R.G.I. gratefully acknowledges a fellowship from the Italian Cystic Fibrosis Research Foundation. A. Carvalho and C. Cunha were financially supported by fellowships from the Fundação para a Ciência e Tecnologia, Portugal (contracts SFRH/BPD/46292/2008 and SFRH/BD/65962/2009, respectively).

Author Contributions: R.G.I. performed most of the in vivo murine experiments, and analyzed and interpreted data. A. Carvalho and C. Cunha supervised and performed the genotypic analysis on human cells. T.Z., A.D.L., and G.G. contributed to the mouse infection and challenge experiments. F.F. performed intracellular staining and FACS analysis; A. Casagrande and C.V. performed Western blots; C.M.-B. analyzed and scored the histopathology samples. G.D. and M.R. performed microbiology in clinical samples; L.P. performed CF genotyping; C. Colombo, L. Ratclif, and F.M.D.B. provided the clinical samples and conceptual advice. R.G.I., A. Carvalho, P.P., and L. Romani designed the experiments, analyzed data, and wrote the paper.

Correspondence and requests for reprints should be addressed to Luigina Romani, M.D., Ph.D., Department of Experimental Medicine and Biochemical Sciences, University of Perugia, Via del Giochetto, 06122 Perugia, Italy. E-mail: Iromani@unipg.it This article has an online supplement, which is available from this issue's table of contents at www.atsjournals.org

Am J Respir Crit Care Med Vol 187, Iss. 6, pp 609-620, Mar 15, 2013 Copyright $\odot 2013$ by the American Thoracic Society

Originally Published in Press as DOI: 10.1164/rccm.201207-1346OC on January 10, 2013 Internet address: www.atsjournals.org

\section{AT A GLANCE COMMENTARY}

Scientific Knowledge on the Subject

The respiratory tract of patients with cystic fibrosis $(\mathrm{CF})$ is colonized with, in addition to bacteria, many fungi, although whether they are primarily responsible for or a consequence of ineffective airway inflammation remains controversial and largely unsolved.

What This Study Adds to the Field

Decreased tryptophan/kynurenine metabolism, as a result of defective indoleamine 2,3-dioxygenase (IDO) enzyme, was causally linked to susceptibility to Aspergillus infection and sensitization in murine $\mathrm{CF}$ through the generation of a type 17 helper T-cell/regulatory T-cell (Th17/Treg) imbalance. Treatments with IDO agonists or prevention of Th17-cell activation restored antifungal protective immunity and improved lung inflammation and function, suggesting a therapeutic potential for IDO-mimetic drugs in $\mathrm{CF}$.

Conclusions: This study provides a link between tryptophan catabolism and lung immune homeostasis in murine CF, representing a proof-of-concept that targeting pathogenic inflammation via IDO-mimetic drugs may benefit patients with CF.

Keywords: cystic fibrosis; indoleamine 2,3-dioxygenase; Th17/Treg balance; aspergillosis

The respiratory system in patients with cystic fibrosis (CF) is characterized by high concentrations of neutrophils (1) and proinflammatory cytokines, including IL-17A (2-4), with reduced concentrations of antiinflammatory factors $(5,6)$. Type 17 helper $\mathrm{T}$ (Th17) lymphocytes, and other IL- $17^{+}$cells-including neutrophils, $\gamma \delta \mathrm{T}$ cells, and natural killer T cells-are present in the airway submucosa in patients with $\mathrm{CF}$, and they are presumed to account for the underlying inflammatory status in those patients (4). An exaggerated inflammatory response, relative to the actual burden of infection, is indeed responsible for much of the pathology found in CF lungs $(1,7,8)$. We have shown that IL-17A/Th17 cells are at the intersection of immune protection with pathology in fungal infections (9). Indeed, Th17 cells are in balance with regulatory $\mathrm{T}$ (Treg) cells through the activity of indoleamine 2,3-dioxygenase (IDO), the rate-limiting enzyme in tryptophan degradation along the kynurenine pathway (10). Pathogenic Th17 cells, owing to IDO deficiency, account for the 
inherent susceptibility to aspergillosis in mice with chronic granulomatous disease, because of an unopposed inflammatory response that compromises the host's ability to eradicate infection (11). These findings may be relevant in patients with $\mathrm{CF}$ whose respiratory tract is colonized, in addition to bacteria, by many fungi (12-14), although their involvement in respiratory infections remains controversial and largely unsolved. Indeed, although the effects of fungal colonization on lung function have remained unclear (15), colonization with Aspergillus fumigatus in CF may be associated with decreased $\mathrm{FEV}_{1}$ and a more rapid decline in pulmonary function, even in the absence of allergic bronchopulmonary aspergillosis (ABPA) $(16,17)$, a hypersensitivity condition to Aspergillus colonization, affecting about $10 \%$ of people with CF (14). Because the use of inhaled corticosteroids is not apparently associated with a greater risk of Aspergillus infection in patients with $\mathrm{CF}$, as opposed to the non-CF population (18), it has been suggested that individuals with CF may have a specific susceptibility to infection with filamentous fungi (14).

In this study, we assessed whether the inability to properly control inflammation could contribute to the susceptibility to respiratory fungal infections in CF. We tested the hypothesis that IDO deficiency may influence Aspergillus-dependent lung diseases in CF. Considering that tryptophan metabolites are also able to impair calcium mobilization in T cells (19), a role for IDO in the control of T-cell dysreactivity due to disturbed $\mathrm{Ca}^{2+}$ signaling pathways (20) is likely. We resorted to $C f t r^{t m 1 U n c}\left(C f r^{-1-}\right)$ mice-known to mimic, to some extent, human CF (21) - to verify that defective IDO leads to unopposed Th17-cell responses to A. fumigatus. We found that IDO is under genetic and transcriptional control in $\mathrm{CF}$, that its deficiency is present in patients with the $\Delta \mathrm{F} 508$ mutation and experimental $\mathrm{CF}$, and that it is causally linked to pathogenic Th17-cell responses to the fungus. We also obtained a proof-of-concept demonstration that targeting the Th17/Treg-cell imbalance in vivo through IDO restoration has curative effects. These findings pave the way to immune therapies in CF that would target pathogenic inflammation via tryptophan metabolism. Some of the results of these studies have been previously reported in the form of an abstract (22).

\section{METHODS}

\section{Animals}

Six- to 8-week-old C57BL/6 mice were purchased from Charles River (Calco, Italy). Genetically engineered homozygous $\mathrm{Cftr}^{-1-}$ mice (23) were bred at the Cystic Fibrosis Core Animal Facility at San Raffaele Hospital (Milan, Italy). $I l 10^{-/-}$and Indo $o^{-/}$mice were bred at the Animal Facility of the University of Perugia (Perugia, Italy). Experiments were performed according to Italian Approved Animal Welfare Assurance 245-2011-B.

\section{Infection, ABPA, and Treatments In Vivo}

Mice were anesthetized by intraperitoneal injection of $2.5 \%$ Avertin (Sigma Chemical Co, St. Louis, MO) before intranasal instillation of $2 \times 10^{7}$ A. fumigatus (Af293) resting conidia per $20 \mu$ lof saline. For histology, paraffin-embedded tissue were stained with periodic acidSchiff (PAS) and Gomori, and bronchoalveolar lavage (BAL) fluid collection was done as described (24). For ABPA, mice received an intraperitoneal and a subcutaneous injection of $100 \mu \mathrm{g}$ of $A$. fumigatus culture filtrate extract (CCFA) dissolved in Freund's incomplete adjuvant (Sigma) followed by two consecutive intranasal injections (1 wk apart) of $20 \mu \mathrm{g}$ of CCFA (25). Additional details are reported in the online supplement.

\section{Human Bronchial Epithelial Cells}

Human bronchial epithelial (HBE) cells homozygous for the $\Delta \mathrm{F} 508$ mutation were obtained from three lung transplants (patients with
$\mathrm{CF}$ ) or lung resections (patients without $\mathrm{CF}$ ) and cultured as described (26). Unpolarized cells were exposed to recombinant IFN- $\gamma(100 \mathrm{U} / \mathrm{ml}$; Santa Cruz Biotechnology, Santa Cruz, CA), A. fumigatus resting conidia at a cell-to-fungi ratio of 2:1, and $10 \mu \mathrm{g} / \mathrm{ml}$ poly(I:C) (SigmaAldrich). Cells were incubated for 18 hours at $37^{\circ} \mathrm{C}$ in $5 \% \mathrm{CO}_{2}$ and then stained with mouse anti-human IDO antibody clone 10.1 (Millipore, Billerica, MA) and analyzed for IDO protein expression by Western blotting and for kynurenine content by high-performance liquid chromatography.

\section{Western Blotting}

Blots were incubated with murine anti-human IDO antibody (Millipore) or rabbit polyclonal anti-murine IDO antibodies (27). Normalization was performed with mouse anti- $\beta$-tubulin antibody (Sigma-Aldrich) and quantification was obtained by densitometric image analysis using Image Lab 3.1.1 software (Bio-Rad, Segrate, Italy).

\section{Immunohistochemistry}

Lung sections were deparaffinized and stained with phycoerythrin (PE)anti-IL-17A (eBioscience, San Diego, CA), PE-anti-IL-10 (eBioscience), PE-anti-IFN- $\gamma$ (eBioscience), rabbit polyclonal antibody to forkhead box protein P3 (FOXP3; Abcam, Cambridge, UK), fluorescein isothiocyanate (FITC)-anti-CD4 (Miltenyi Biotec, Bologna, Italy), and polyclonal antiIDO rabbit antibodies followed by goat anti-rabbit FITC secondary antibody (Sigma-Aldrich).

\section{Terminal Deoxynucleotidyltransferase-mediated Deoxyuridine Triphosphate Nick-End Labeling of Lung Sections}

The lungs were fixed in $4 \%$ buffered paraformaldehyde, $\mathrm{pH} 7.3$, for 36 hours and embedded in paraffin. Sections were deparaffinized, rehydrated, and treated with $0.1 \mathrm{M}$ citrate buffer, $\mathrm{pH}$ 6.0, for 20 minutes in a water bath, and washed and blocked in $0.1 \mathrm{M}$ Tris- $\mathrm{HCl}$ buffer, $\mathrm{pH}$ 7.5, supplemented with $3 \%$ bovine serum albumin and $20 \%$ fetal calf serum. The slides were then incubated with fluorescein-coupled dUTP and terminal deoxynucleotidyltransferase-mediated deoxyuridine triphosphate nick-end labeling (TUNEL) enzyme (Roche Diagnostics, Milan, Italy) in the presence of terminal deoxynucleotidyltransferase. The samples were then washed with phosphate-buffered saline and incubated for 10 minutes at $70^{\circ} \mathrm{C}$ to remove unspecific binding. The sections were mounted and analyzed by fluorescence microscopy, using a $\times 40$ objective.

\section{Kynurenine and Tryptophan Assay}

Kynurenine concentrations (micromolar) in the supernatants of 18-hour HBE cell cultures were measured by high-performance liquid chromatography (11). The kynurenine-to-tryptophan ratio was determined as described (28).

\section{Statistical Analysis}

Results are expressed as means \pm SEM. Statistical analysis was performed by Student $t$ test or analysis of variance and Bonferroni's test and analyzed with the GraphPad Prism 4.03 program (GraphPad Software, San Diego, CA). Values of $P$ not greater than 0.05 were considered significant.

\section{RESULTS}

\section{CF Mice Are Susceptible to Aspergillus fumigatus Infection and Sensitization}

To assess whether IDO deficiency could affect infection and sensitization to A. fumigatus in mice, we evaluated the susceptibility of $\mathrm{C} 57 \mathrm{BL} / 6$ and $\mathrm{Cftr}^{-1-}$ mice to pulmonary aspergillosis or fungal sensitization in the ABPA model and evaluated parameters of infection, lung inflammation, and innate and adaptive Th immunity. In infection, although fungal growth was only slightly greater in $\mathrm{Cftr}^{-1-}$ than control mice (Figure 1A), a sustained and 
A

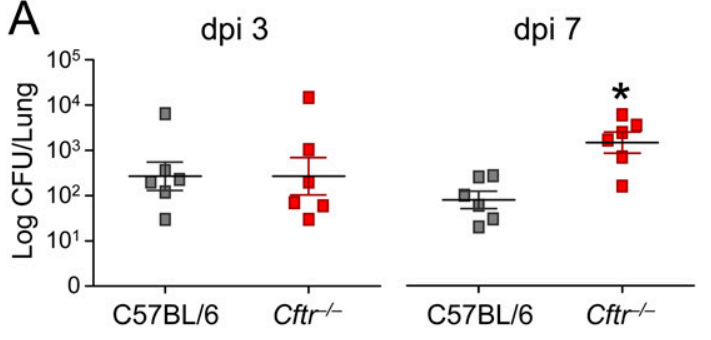

B Total cells

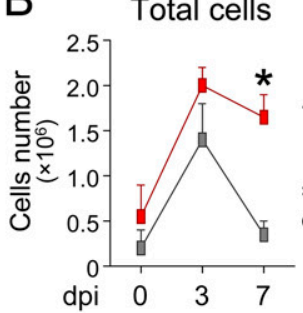

MNC

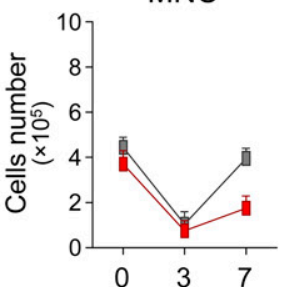

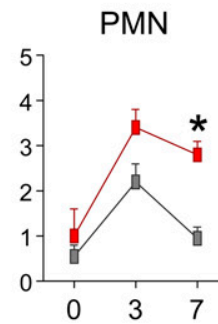

$\mathrm{Cftr}^{-1}$
C

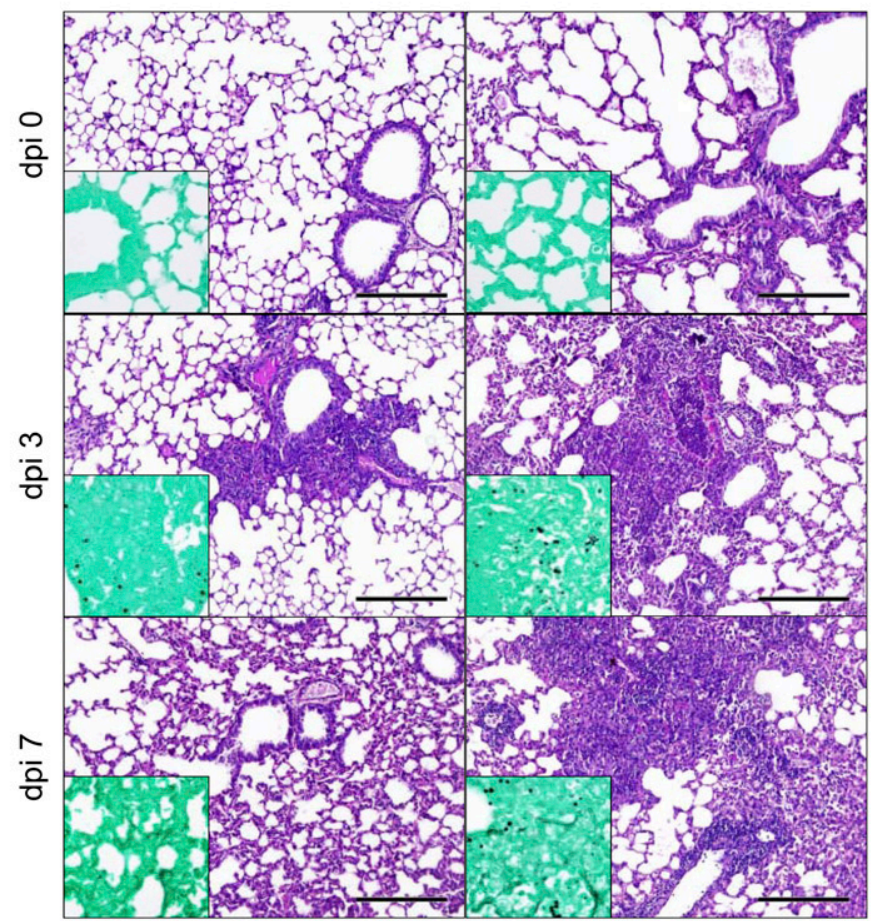

D
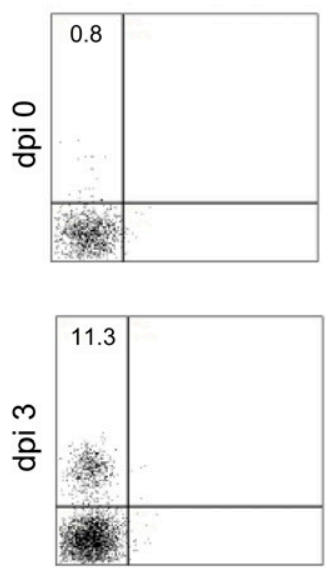

$\mathrm{Cftr}^{-1}$
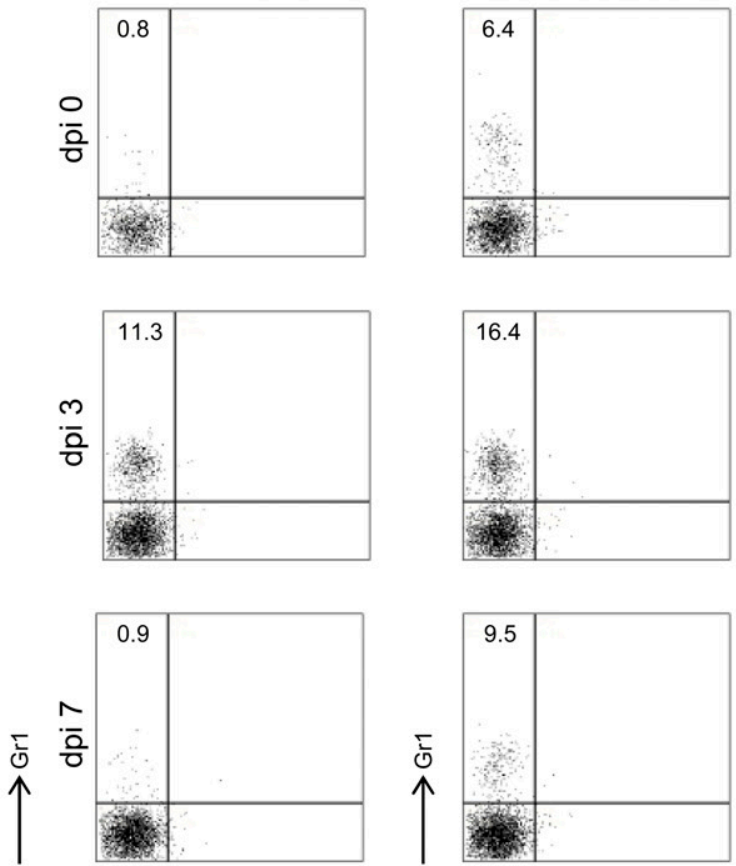

E

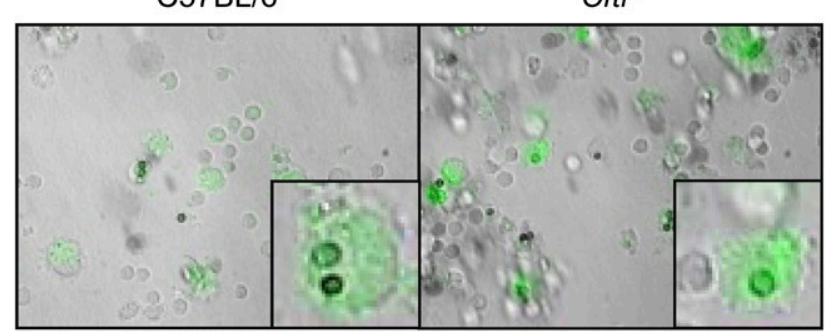

F

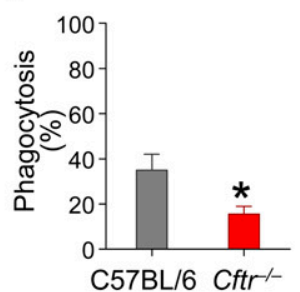

G

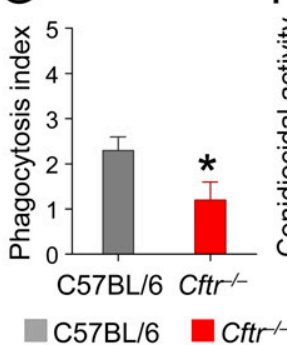

$\mathrm{H}$

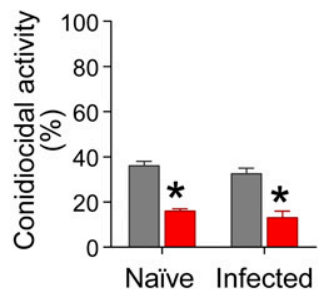

Figure 1. Cystic fibrosis (CF) mice are susceptible to Aspergillus fumigatus infection. C57BL/6 and $\mathrm{Cftr}^{-1-}$ mice (six per group) were infected intranasally with live $A$. fumigatus conidia. (A) Fungal growth ( $\log _{10} \mathrm{cfu}$, mean \pm SEM) in the lungs 3 and 7 days postinfection (dpi). (B) Bronchoalveolar lavage (BAL) morphometry at various days postinfection. Differential cell count of mononuclear cells (MNC), polymorphonuclear cells $(\mathrm{PMN})$, and eosinophils (EOS) was determined on May-Grünwald Giemsa staining. Values represent the mean \pm SEM of three mice per group and are representative of five independent experiments. (C) Lung histology (periodic acid-Schiff and, in the inset, Gomori staining) at various days postinfection. Photographs were taken with a high-resolution microscope (Olympus DP71) equipped with a $\times 20$ objective and (in the inset) a $\times 40$ objective. Scale bars, $200 \mu \mathrm{m}$. (D) Numbers of granulocyte-differentiation antigen-1 (Gr1)-positive cells were assessed by flow cytometry of total lung cells on various days postinfection. $(E)$ Phagocytic activity, $(F)$ percent ingestion of $A$. fumigatus conidia, and $(G)$ phagocytosis index (mean number of ingested conidia per cell) of total lung cells exposed to live green fluorescent protein-expressing conidia for 2 hours at $37^{\circ} \mathrm{C}$ (representative microscopy images of two independent experiments). Data were pooled from three independent experiments. $(H)$ Conidiocidal activity (percentage of colony-forming unit inhibition [mean $\pm \mathrm{SE}$ ]) of total lung cells from naive or infected mice at $3 \mathrm{dpi}$. ${ }^{*} P<0.05, \mathrm{Cftr}{ }^{-/}$versus $\mathrm{C} 57 \mathrm{BL} / 6 \mathrm{mice}$.

persistent inflammatory response, characterized by neutrophil and eosinophil recruitment in the BAL (Figure 1B) and lung (Figures 1C and 1D), was observed in $\mathrm{Cftr}^{-/-}$mice, in which a degree of inflammation was already visible before the infection (Figure 1C). Despite recruitment, both the phagocytic and conidiocidal activities of lung cells were reduced in $\mathrm{Cftr}^{-/-}$mice 
as compared with wild-type mice (Figures $1 \mathrm{E}-1 \mathrm{H}$ ), a finding indicative of an impaired activity of the recruited cells. Defective phagolysosome acidification in the setting of CFTR mutation conducive to microbial replication has indeed been described (29). In ABPA, PAS-stained sections of lung indicated a greater degree of mucous cell hyperplasia in $\mathrm{Cftr}^{--}$than control mice (Figure 2A) that was associated with eosinophil infiltration (Figure $2 \mathrm{~A}$, inset) and extraordinarily high levels of total serum $\mathrm{IgE}$, reaching over $20,000 \mathrm{pg} / \mathrm{ml}$ (Figure 2B), and of Muc5 mRNA expression in the lungs (Figure $2 \mathrm{C}$ ). These data suggest that $\mathrm{CF}$ mice are susceptible to Aspergillus infection and allergy.

\section{Inflammatory Cytokines and Th17/Th2-Cell Responses Are Up-regulated in $\mathrm{Cftr}^{-/-}$Mice}

The heightened and unresolved inflammatory response in $\mathrm{Cftr}^{-1-}$ mice was associated with high levels of tumor necrosis factor (TNF)- $\alpha$, IL-6, and IL-1 $\beta$ in the BAL during infection and, for TNF- $\alpha$ and IL-6, even before infection (Figure 3A). For the assessment of Th-cell activation, we measured levels of Th cytokines in the lungs and of the corresponding transcription factors in the draining thoracic lymph nodes. Th1 cytokines (IL-12p70/ IFN- $\gamma$ ) and Th1-cell activation (Tbet expression), although higher in uninfected $\mathrm{Cftr}^{-1-}$ than wild-type mice, failed to increase in infection in $\mathrm{Cftr}^{-1-}$ mice (Figure 3B). The levels of IL-4 and IgE were higher in $\mathrm{Cftr}^{-1-}$ than in wild-type mice, both uninfected and throughout infection, whereas the levels of IL-5 and IL-13 increased in $\mathrm{Cftr}^{-1-}$ mice 1 week after infection, in concomitance with Th2-cell activation (Gata3 expression)

A
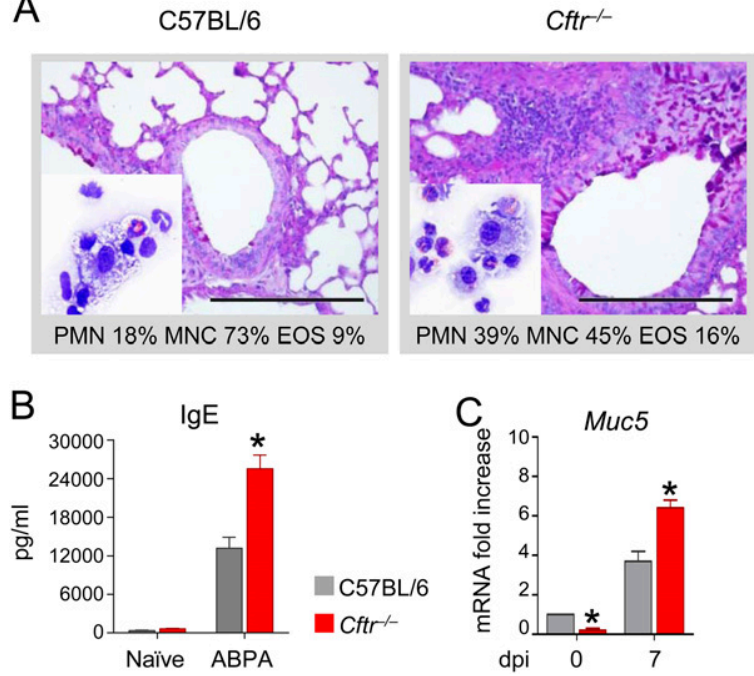

Figure 2. Cystic fibrosis (CF) mice are susceptible to Aspergillus fumigatus allergy. Allergic bronchopulmonary aspergillosis (ABPA) was induced by repeated injection of mice with $A$. fumigatus culture filtrate extract dissolved in Freund's incomplete adjuvant followed by intratracheal infection with resting conidia 1 week after the last injection. $(A)$ Lung histology (periodic acid-Schiff staining) 1 week after the intranasal infection (numbers refer to percent mononuclear cells [MNC], polymorphonuclear cells [PMN], and eosinophils [EOS] in the bronchoalveolar lavage) (magnified in the inset). Photographs were taken with a high-resolution microscope (Olympus DP71) equipped with a $\times 40$ objective $(\times 100$ in the insets). Scale bars, $200 \mu \mathrm{m}$. (B) Total serum IgE levels (ELISA) and (C) expression of Muc5 gene (RT-PCR on lung cells) 1 week after the last injection. ${ }^{*} P<0.05, \mathrm{Cttr}^{-1}$ versus $\mathrm{C} 57 \mathrm{BL} / 6$ mice. Data are from a representative experiment (histology) or represent pooled results from two independent experiments. $\mathrm{dpi}=$ days postinfection.
(Figure 3C). The Th17 cytokines IL-23, IL-17A, and IL-17F started to increase in $\mathrm{Cftr}^{-1-}$ mice 1 week after infection and remained elevated thereafter (Figure 3D), concomitant with robust Th17-cell activation (Rorc expression) (Figure 3D). Despite being produced by Th17 cells, IL-22 has shown autonomous protective functions against fungi $(27,30)$. In human $\mathrm{CF}$, inducible $\mathrm{IL}-17^{+} \mathrm{IL}-22^{+}$memory cells were expanded in the draining lymph nodes (31), but low levels of IL22 mRNA were observed in the sputum (2). We found that IL-22 production was lower in $\mathrm{Cftr}^{-1-}$ mice and was associated with progressively down-regulated expression of the aryl hydrocarbon receptor (AhR), a ligand-dependent transcription factor that mediates IL-22 production (32), in the draining lymph nodes (Figure 3E). Finally, the levels of IL-10 were consistently lower in $\mathrm{Cftr}^{-1-}$ mice than in wild-type mice, as it was with Foxp3 expression on T cells (Figure $3 \mathrm{~F})$. These results indicate that, in addition to Th2-cell responses, heightened Th17-cell responses are observed in $\mathrm{Cftr}^{-1-}$ mice concomitant with defective protective antifungal responses, such as those mediated by IL-22 (30) and the Th1/Treg axis (33).

\section{IL-17A-Producing $\gamma \delta$ T Cells Are Expanded and Foxp $3^{+}$Treg Cells Are Defective in $\mathrm{Cftr}^{-/-}$Mice}

Immunostaining of lungs and phenotypic analysis of lung cells confirmed the imbalance of Th17/Treg cells in $\mathrm{Cftr}^{-1-}$ mice. We found that a population of IL-17A-producing $\gamma \delta \mathrm{CD}^{+} \mathrm{T}$ cells was expanded in infection in the lungs of $\mathrm{Cftr}^{-/-}$mice (Figure $4 \mathrm{~A}$ ), IFN- $\gamma^{+} \mathrm{CD} 4^{+}$T cells were expanded in wild-type mice (Figure 4B), and IL-10-producing (Figure 4C) or Foxp3 ${ }^{+}$(Figure 4D) $\mathrm{CD}^{+} \mathrm{T}$ cells were present in wild-type more than in $\mathrm{Cftr}^{-1-}$ mice. Phenotypic analysis confirmed that $\gamma \delta \mathrm{CD}^{+} \mathrm{T}$ cells expanded (from 4.4 to $19 \%$ ) in $\mathrm{Cftr}^{-1-}$ mice more than in wild-type mice (from 6.3 to $8 \%$ ) (Figure $4 \mathrm{E}$ ) and produced IL-17A and not IFN- $\gamma$, as revealed by intracellular cytokine staining (Figure 4F). CD $4^{+} \mathrm{CD} 25^{+} \mathrm{T}$ cells were instead present in both types of mice (Figure 4G), although they were not "bona fide" Treg cells as they were associated with defective IL-10 production. Thus, IL-17A-producing $\gamma \delta \mathrm{T}$ cells are expanded in both human (4) and murine CF whereas Foxp ${ }^{+}$Treg cells are restrained.

\section{IDO Is Defective in CF Mice}

We next evaluated whether defective IDO is demonstrable in $\mathrm{Cftr}^{-1-}$ mice, either uninfected or infected with Aspergillus. The levels of expression of IDO protein, as revealed by Western blotting (Figure 5A) and immunofluorescence staining (Figure $5 \mathrm{D}$ ), and of the Ido1 gene (Figure 5B) were lower in the lungs of $\mathrm{Cftr}^{-/}$mice than in wild-type mice, either uninfected or infected. Similarly lower was the kynurenine-to-tryptophan ratio, a reliable indicator of IDO activity (28) (Figure 5C). The expressions of Kmo, Куnu and Haao, a series of genes encoding enzymes downstream of IDO (11), were also reduced in $\mathrm{Cftr}^{-\mathrm{l}}$ mice (Figure 5E). On assessing Idol expression in purified lung dendritic cells (DCs) in response to various stimuli, we found it lower in $\mathrm{Cftr}^{-1-}$ DCs than in wild-type DCs (Figure 5F) and associated with less IL-10 and more IL-23 production (Figure 5G). Consistent with the notion that defective IDO in DCs is responsible for deregulated inflammation and immunity to the fungus (25), $\mathrm{Cftr}^{-1-}$ DCs induced IL-4 and IL-17A, more than IL-10, production on coculture with $\mathrm{CD}^{+} \mathrm{T}$ cells from wild-type mice (Figure 5H). A similar pattern of cytokine production was observed in cocultures of $\mathrm{CD}^{+} \mathrm{T}$ cells from $\mathrm{Cftr}^{-1-}$ mice with either type of DCs or on $\mathrm{T}$ cell receptor stimulation (Figure $5 \mathrm{H}$ ). These findings indicated that IDO deficiency in DCs may contribute to the dysfunctional Th-cell reactivity described in CF (34-36) and 
A

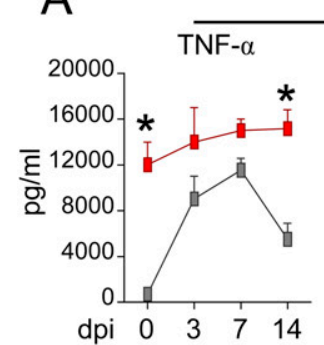

Inflammatory pathway

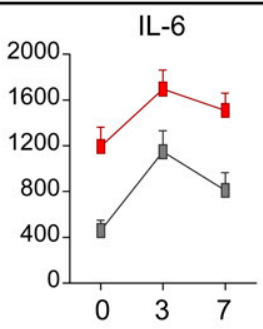

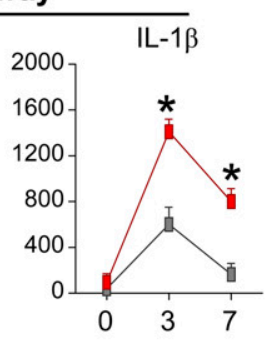

B

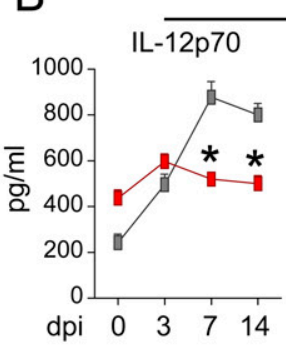

Th1 pathway

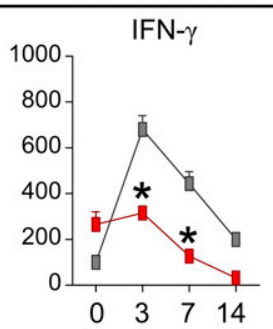

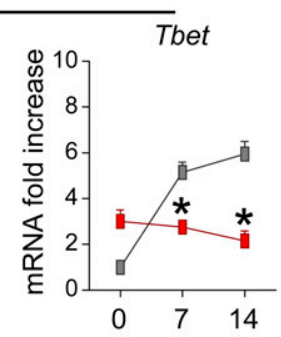

C

Th2 pathway
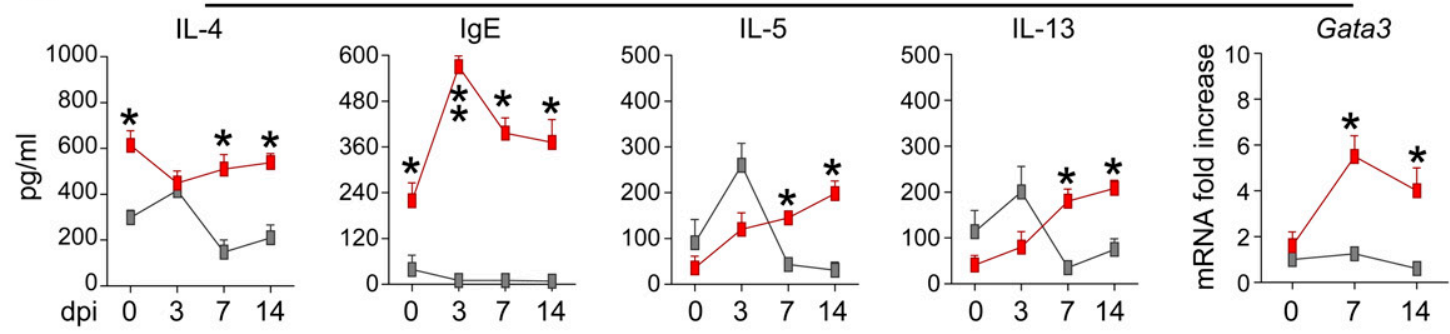

Th17 pathway
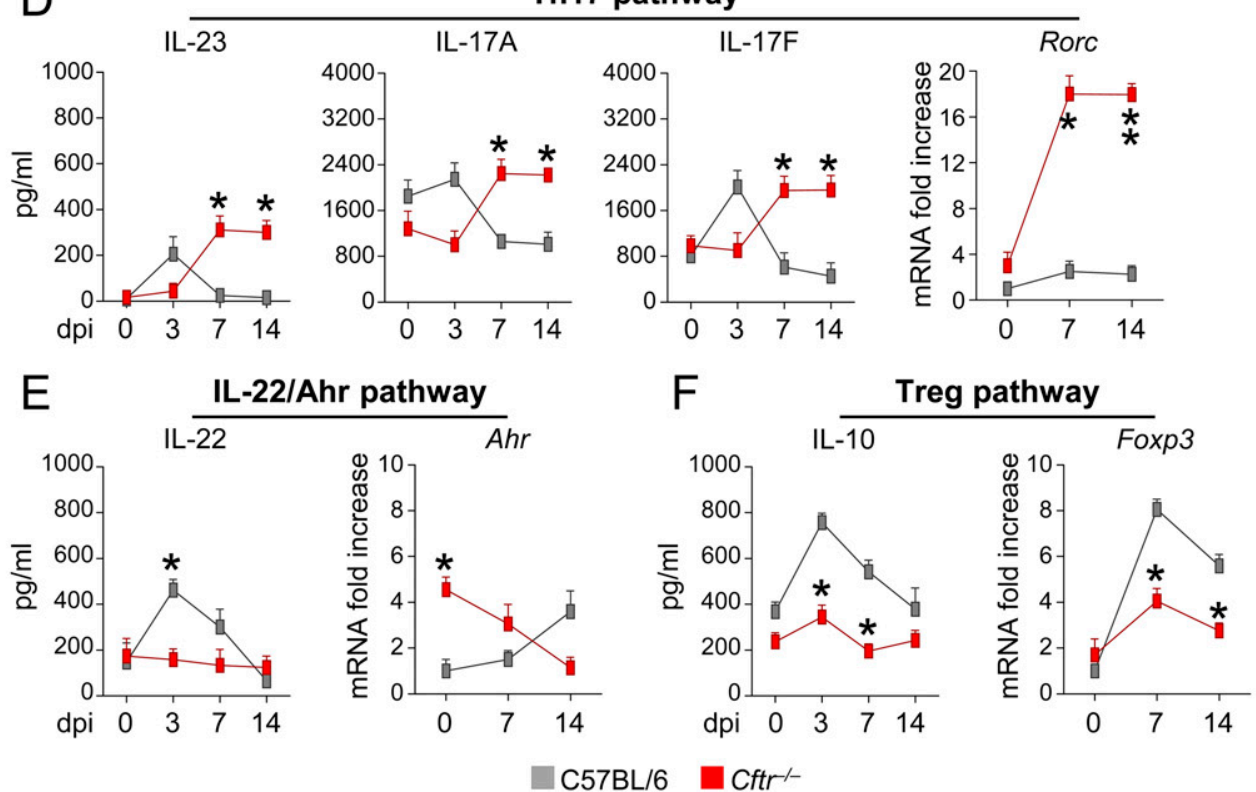

C57BL/6 $\mathrm{Cftr}^{-}$

Figure 3. Inflammatory cytokines and type 17 helper T-cell/regulatory T-cell (Th17/Treg) responses are up-regulated in $C f t r^{-/}$mice. $(A-F)$ Time $^{-1}$ course of cytokine production (mean values \pm SEM, ELISA on lung homogenates) on various days postinfection (dpi) and of Th cell-specific transcripts (RT-PCR on purified $\mathrm{CD}^{+}{ }^{+} \mathrm{T}$ cells from draining lymph nodes) in $\mathrm{C} 57 \mathrm{BL} / 6 \mathrm{or} \mathrm{Cftr}^{-1-}$ mice infected intranasally with live Aspergillus fumigatus resting conidia. ${ }^{*} P<0.05 ;{ }^{* \star} P<0.01, \mathrm{Cftr}^{-/-}$versus $\mathrm{C} 57 \mathrm{BL} / 6$ mice (data represent pooled results from three experiments). Ahr $=$ aryl hydrocarbon receptor; Foxp $3=$ forkhead box protein P3; Rorc = retinoic acid receptor-related orphan receptor C; Tbet $=\mathrm{T}$ box expressed in T cells; TNF- $\alpha=$ tumor necrosis factor- $\alpha$.

prompted us to investigate the environmental mechanisms behind defective IDO activity.

\section{IDO Expression Is Sensitive to Intracellular $\mathrm{Ca}^{2+}$ Flux}

IDO and tryptophan metabolites are known to impair calcium mobilization in T cells (19). However, whether the enhanced intracellular $\mathrm{Ca}^{2+}$ flux and elevated nuclear levels of nuclear factor of activated T cells (NFAT), observed in the absence of CFTR $(20,35)$ and known to impact on DC functioning (37), negatively affect IDO expression is not known. We found that IDO expression in DCs was sensitive to the $\mathrm{Ca}^{2+}$ signaling pathway, as enhancing intracellular $\mathrm{Ca}^{2+}$ flux by ionomycin or blocking the calcineurin/NFAT pathway by cyclosporine A (CsA) inhibited or promoted, respectively, IDO gene (Figure 5I) and protein (Figure 5J) expression. Thus, genetic and transcriptional regulatory mechanisms contribute to dysfunctional IDO activity that, in turn, sustains dysregulated inflammation in CF.

\section{IDO Deficiency Contributes to the Th17/Treg Imbalance in $\mathrm{CF}$ Mice}

To directly prove that IDO deficiency and the ensuing imbalance between inflammatory Th17 and antiinflammatory Treg cells are causally linked to susceptibility to infection of $\mathrm{Cftr}^{-1-}$ mice, we resorted to IDO- or IL-10-deficient mice. The inflammation (see Figure E1A in the online supplement) and fungal growth (Figure E1B) were both heightened in IDO or IL-10 deficiency 
A dpi 0
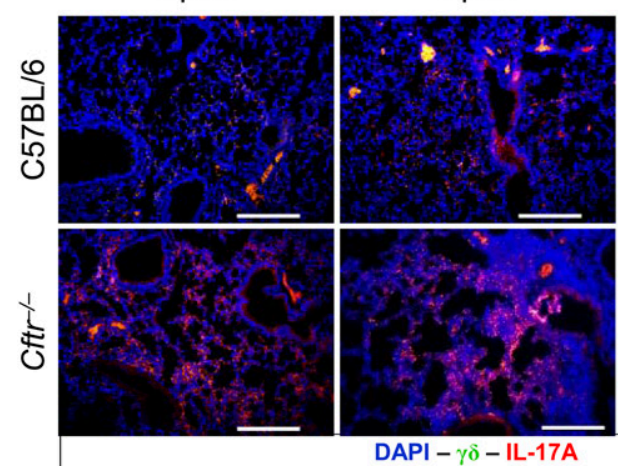

DAPI - $\gamma \delta$ - IL-17A
B dpi 0
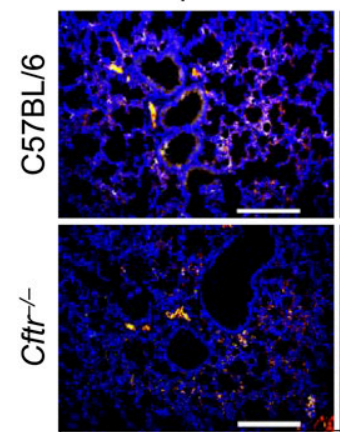

dpi 3

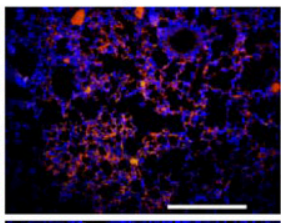

dpi 7

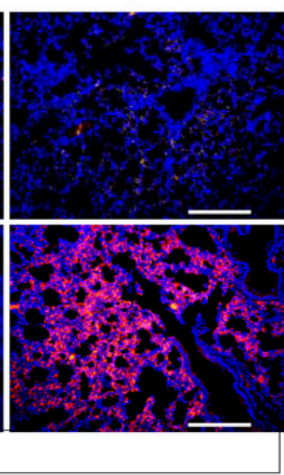

C dpi 0
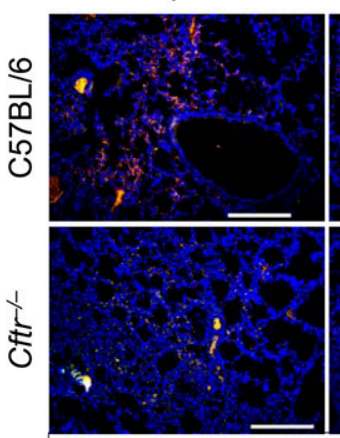

dpi 3

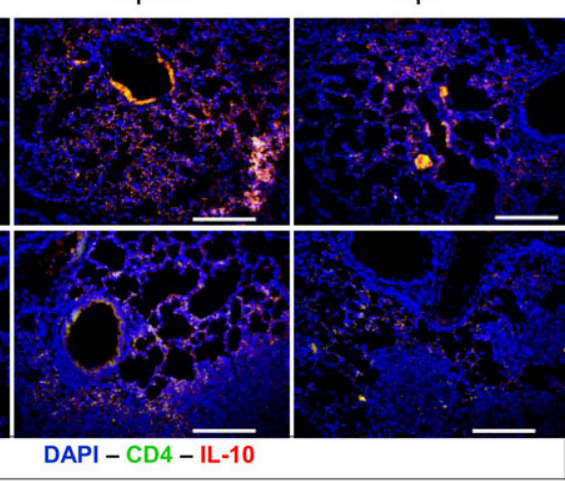

dpi 7

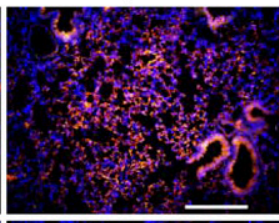

DAPI - CD4 - IFN-

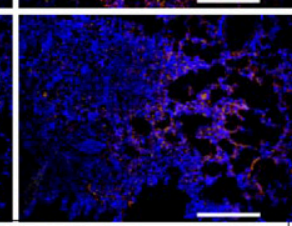

D dpi 0

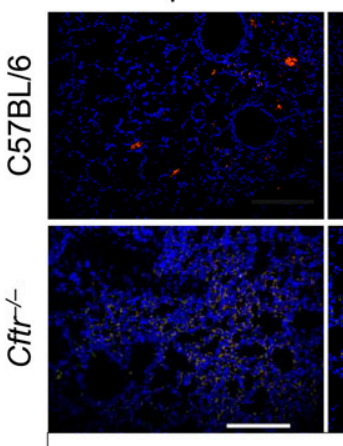

dpi 3

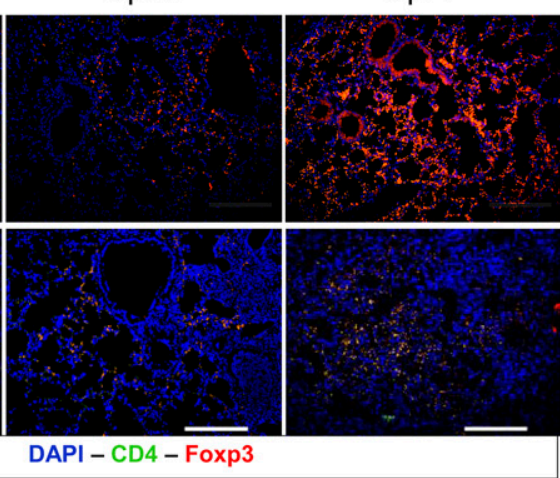

E

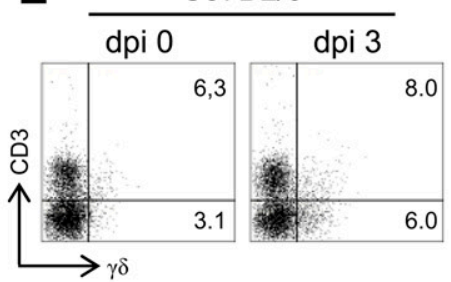

$\mathrm{F}$
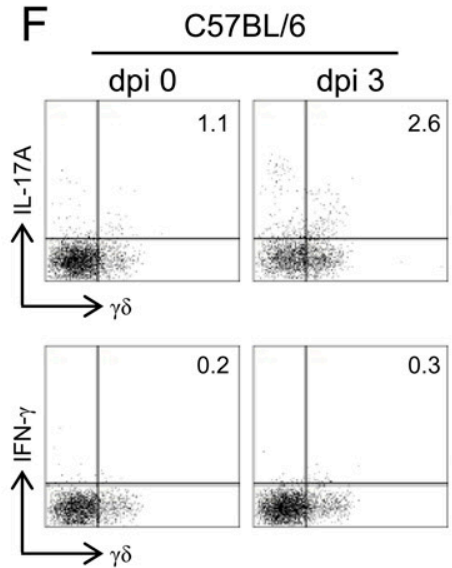
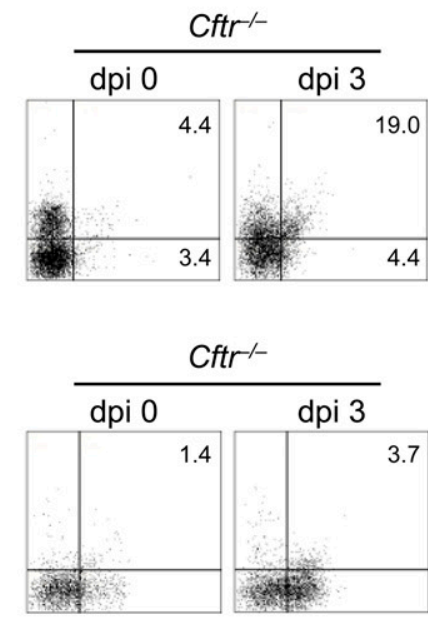

G

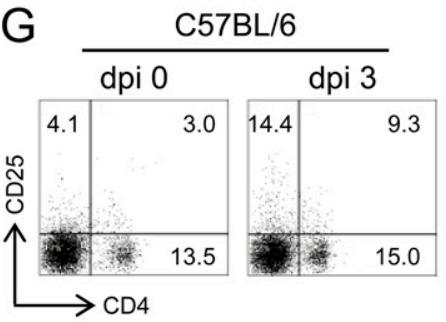

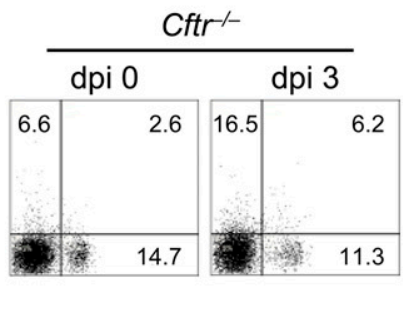

Figure 4. IL-17A-producing $\gamma \delta \mathrm{T}$ cells are expanded and Foxp $3^{+}$regulatory $\mathrm{T}$ (Treg) cells are defective in $\mathrm{Cftr}{ }^{-/} \mathrm{mice} \mathrm{C} 57 \mathrm{BL} / 6$ and $\mathrm{Cftr} r_{-}^{-/}$mice were infected intranasally with live Aspergillus fumigatus conidia. (A) Immunofluorescence staining of lungs 0,3 and 7 days postinfection (dpi) with antiIL-17A conjugated with phycoerythrin (PE) and anti- $\gamma \delta$ conjugated with fluorescein isothiocyanate (FITC), (B) anti-IFN- $\gamma$ PE and anti-CD4 FITC, (C) anti-IL-10 PE and anti-CD4 FITC, and (D) anti-Foxp3 PE and anti-CD4 FITC. Cell nuclei were stained blue with 4',6-diamidino-2-phenylindole (DAPI). (E) Detection of $\mathrm{CD}^{+} \gamma \delta \mathrm{T}$ cells by flow cytometry in the lungs of $\mathrm{C} 57 \mathrm{BL} / 6$ or $\mathrm{Cftr}^{-/-}$mice either uninfected (0 dpi) or 3 days after infection (3 dpi). $(F)$ Intracellular staining for IFN- $\gamma$ and IL-17A in $\mathrm{CD}^{+} \gamma \delta \mathrm{T}$ cells purified from the lungs of $\mathrm{C} 57 \mathrm{BL} / 6$ and $\mathrm{Cftr}{ }^{-/-}$mice. Numbers refer to percentages of positive cells. (G) Detection of $\mathrm{CD} 4^{+} \mathrm{CD} 25^{+}$cells by flow cytometry in the lungs of $\mathrm{C} 57 \mathrm{BL} / 6$ or $\mathrm{Cftr}{ }^{-1-}$ mice. Numbers refer to the percentages of positive cells. Representative images of two independent experiments were acquired with a $\times 20$ objective. Scale bars, $200 \mu \mathrm{m}$. 

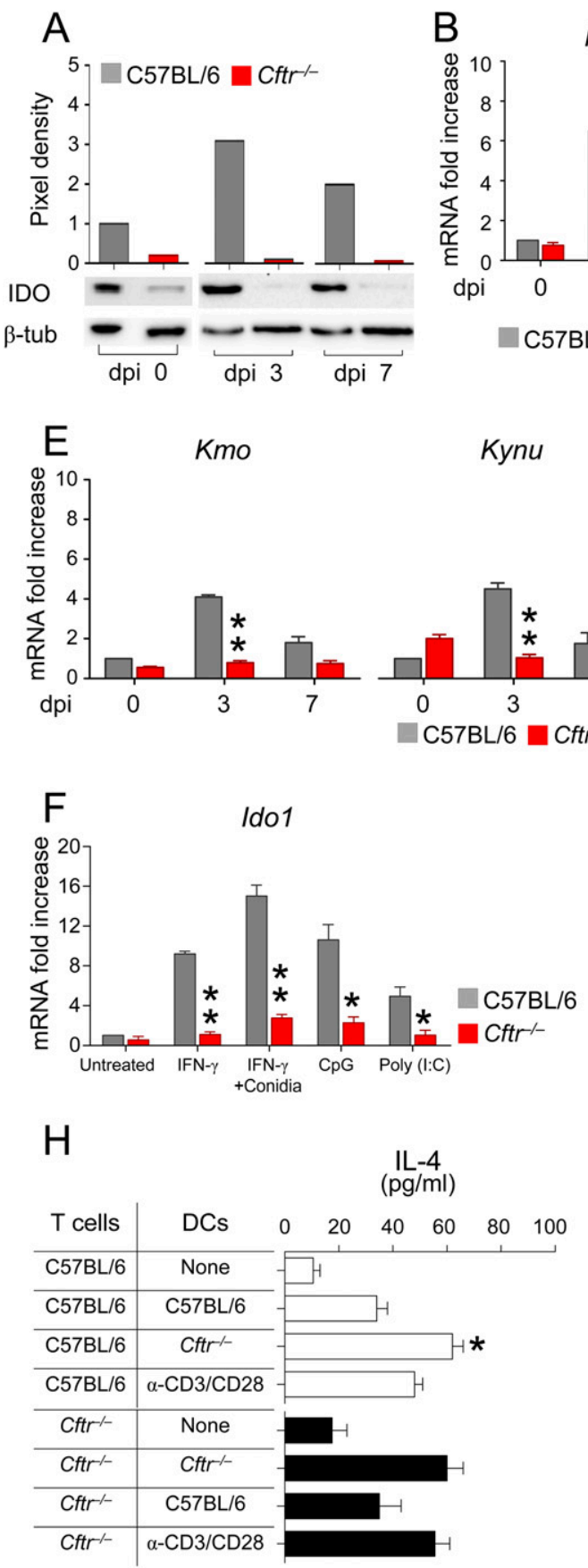

Kynu

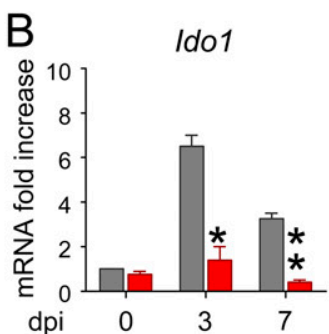

$\square$ C57BL/6 $\square \mathrm{Cftr}^{-1}$
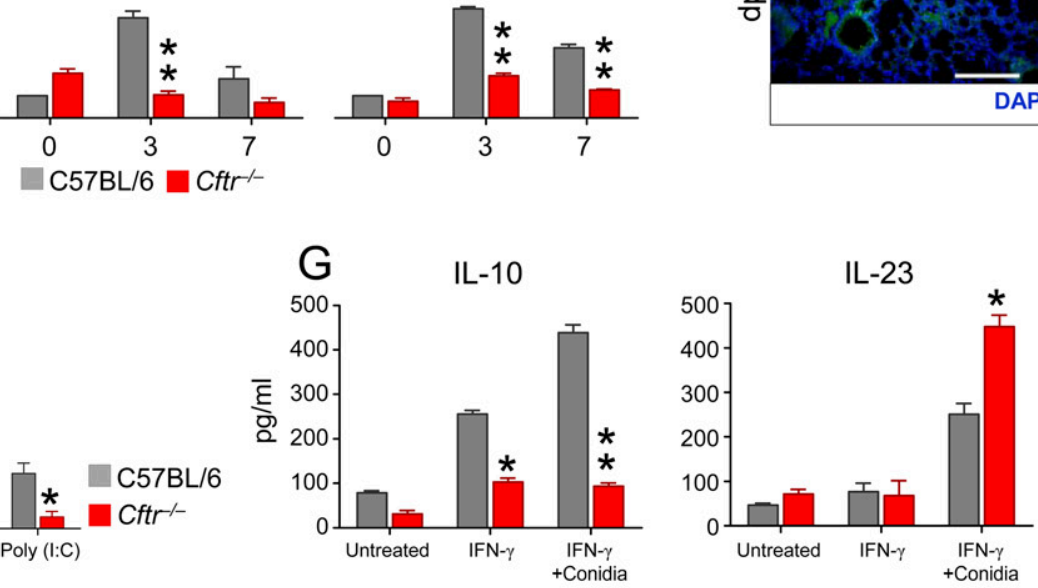

$\mathrm{IL}-10$

IL-17A
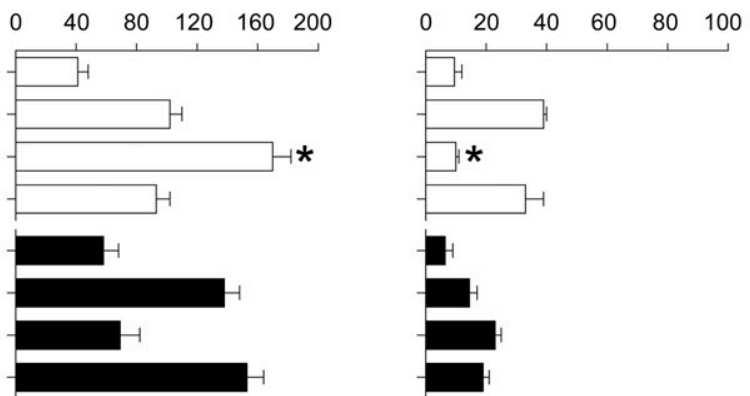
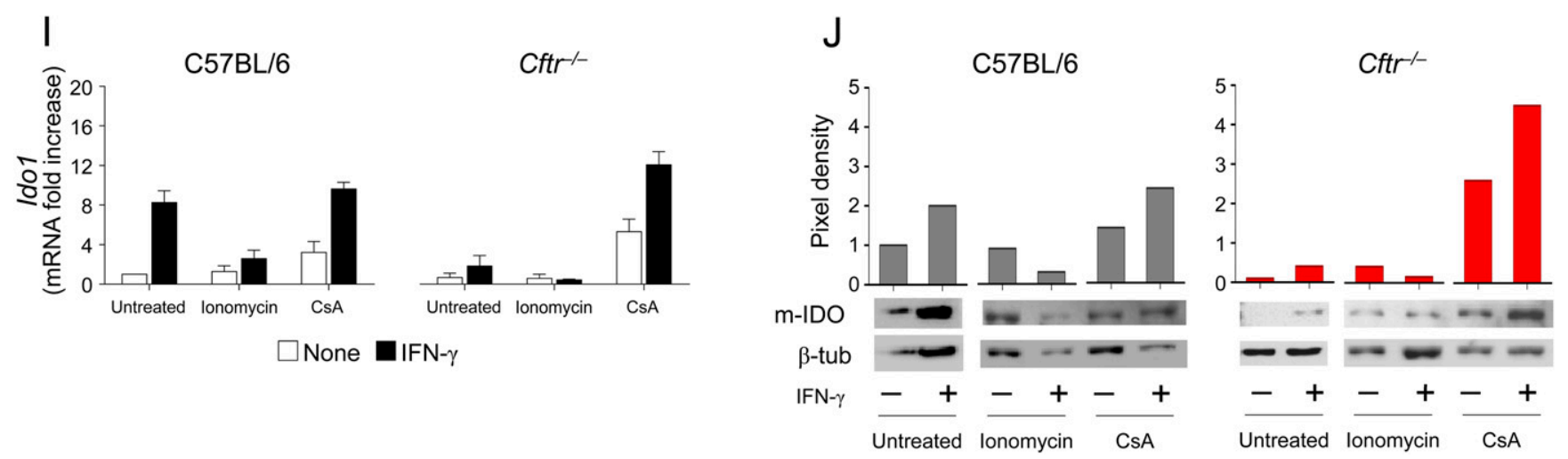
Figure 5. Indoleamine 2,3-dioxygenase (IDO) is defective in cystic fibrosis (CF) mice and contributes to T-cell dysreactivity. Mice (eight per group) were infected intranasally with live Aspergillus fumigatus conidia and assessed for IDO expression in the lung. ( $A$ ) IDO protein expression was analyzed by immunoblotting with rabbit polyclonal IDO-specific antibody on whole lung lysates. Shown are representative Western blots of two independent experiments and corresponding pixel density ratio normalized against $\beta$-tubulin ( $\beta$-tub). (B) Indo transcript expression (RT-PCR) in total lung cells and $(C)$ the kynurenine-to-tryptophan ratio in bronchoalveolar lavage (BAL) of infected mice 3 and 7 days postinfection (dpi). (D) Immunofluorescence lung staining with anti-IDO antibody followed by fluorescein isothiocyanate (FITC) secondary antibody. Cell nuclei were stained blue with 4',6-diamidino-2-phenylindole (DAPI). Representative images of two independent experiments were acquired with a $\times 20$ objective. Scale bars, $200 \mu \mathrm{m}$. (E) Relative expression of Kmo, Kynu, and Haao (RT-PCR) in lung cells on various days postinfection. (F) Indo transcript expression (RT-PCR) and (G) cytokine production (ELISA) by purified lung dendritic cells (DCS) after an 18-hour exposure to the various stimuli. ( $H$ ) Cytokine production (ELISA) in the supernatant of purified lung $\mathrm{T}$ cells from C57BL/6 or $\mathrm{Cftr}^{-1-}$ mice either unstimulated (None) or stimulated in vitro with plate-bound anti-CD3 and soluble anti-CD28 or with Aspergillus-pulsed lung DCs from either type of mice. Shown are pooled results from three independent experiments $(F$ and $H$ ). (I) Indo transcript expression (RT-PCR) and ( $/$ IDO protein expression (immunoblotting with IDO-specific rabbit polyclonal antibody and corresponding pixel density ratio normalized against $\beta$-tubulin) on purified lung DCs unstimulated (-, None) or stimulated with IFN- $\gamma(+)$ and/or ionomycin or cyclosporine $A(C s A)$ for 18 hours. Shown are representative results of two independent experiments. ${ }^{*} P<0.05$; ${ }^{*} \mathrm{P}<0.01, \mathrm{Cftr}^{-1-}$ versus C57BL/6 mice or $\mathrm{Cftr}^{-1-}$ DCs versus C57BL/6 DCs [in $\left.(H)\right]$.

and correlated with low levels of IL-10 production and high levels of IL-17A (Figure E1C). Moreover, directly targeting the IL-17A/Th17 axis by intranasal delivery of silL-17A (small interfering RNA against IL-17A) ameliorated inflammatory pathology (Figure E1D) and the Th17/Treg-cell imbalance (Figure E1E) in $\mathrm{Cftr}^{-/-}$mice. Thus, the Th17/Treg cell imbalance due to IDO deficiency is causally linked to Aspergillus-induced inflammation in $\mathrm{Cftr}^{-/-}$mice.

\section{Restoration of IDO Has Curative Effects in Murine CF}

Given the previously described findings, we tested the efficacy of IDO restoration therapies in $\mathrm{Cftr}^{-/-}$mice with aspergillosis by subjecting them to treatment with IFN- $\gamma, \mathrm{CsA}$, and replacement therapy with a mixture of L-kynurenines, 3-hydroxykynurenine, and 3-hydroxyanthranilic acid downstream in the IDO pathway (11). Each treatment reversed tissue inflammation (Figure 6A) and damage (Figure 6B) and readdressed the Th17/Th2/Tregcell balance in $\mathrm{Cftr}^{-1-}$ mice (Figures 6C and 6D). Treatment with IFN- $\gamma$ and CsA also induced IDO protein (Figure $6 \mathrm{E}$ ) and gene expression (Figure 6F) and, together with kynurenines, the expression of genes encoding enzymes downstream of IDO (Figure $6 \mathrm{G}$ ). These findings expand on our previous data showing the effective treatment of experimental lung inflammation with IDO inducers (11) and reveal a novel mechanism of action for CsA in targeting pathogenic lung inflammation in CF.

\section{IDO Is Defective in Patients with CF}

Defective tryptophan uptake, eventually leading to low kynurenine production, has been demonstrated in human bronchial epithelial (HBE) cells from patients with CF (26). To assess whether defective IDO could also be demonstrated in HBE cells from patients with $\mathrm{CF}$, we evaluated IDO protein expression in $\mathrm{HBE}$ cells from three patients with CF (26) and non-CF control subjects on exposure to Aspergillus conidia and IFN- $\gamma$ (38) or poly(I:C), known IDO inducers (27). IDO protein expression and function were lower in mutant than in control cells, with and without IFN- $\gamma$, as revealed by immunofluorescence staining (Figure 7A), Western blotting (Figure 7B), and decreased levels of secreted kynurenines (Figure 7C). Poly(I:C) restored, albeit partially, IDO expression and function in $\mathrm{CF}$ HBE cells (Figures 7A-7C), suggesting that, like in murine $\mathrm{CF}$, nongenetic control over IDO expression may occur in human $\mathrm{CF}$.

\section{DISCUSSION}

The results of this study show that decreased tryptophan/ kynurenine metabolism may contribute to the inflammatory process in CF. The finding that IDO deficiency was causally linked to a Th17/Treg-cell imbalance responsible for Aspergillus-mediated lung inflammation in experimental CF strongly suggests that IDO may contribute to lung dysfunction and inflammation in CF patients with aspergillosis. Preliminary single-nucleotide polymorphism (SNP) analysis revealed that genetic variants affecting the function of IDO were present in patients with $\mathrm{CF}$ and significantly modulated predicted $\mathrm{FEV}_{1}$ values, a finding consistent with the role of IDO in lung function normalization during lung transplantation (19). However, further studies are needed to establish the possible link between the IDO SNPs and Aspergillus diseases in human CF.

Antiinflammatory drugs have been show to be beneficial in CF patients with ABPA (39). However, adverse effects may limit therapy with oral corticosteroids and ibuprofen (40), and long-term azithromycin therapy has been associated with Aspergillus colonization (41). Thus, to optimize antiinflammatory therapy, it is necessary to further unravel the pathomechanisms of Aspergillus disease in CF (42). We found that, in addition to heightened Th2-inflammatory responses $(43,44)$, Th17 cells are activated in response to the fungus and contribute to the state of chronic lung inflammation in experimental CF. Reduction of the inflammatory response and promotion of more efficient pathogen clearance were achieved by antagonizing Th17-cell responses, a finding consistent with previous observations on Pseudomonas aeruginosa infection in $\mathrm{Cftr}^{-/-}$mice (45). As pathogenic Th17-cell responses are also associated with candidiasis (9), it is not surprising that children with $\mathrm{CF}$ had high prevalence of colonization by Candida albicans (46), whose sensitization has been shown to contribute to ABPA (41). In addition to inhibiting IDO (47), IL-17A was reported to increase fungal adaptation and virulence (48) as well as expression of nucleotide-binding oligomerization domain (NOD)-like receptors (49) that may contribute to unrestrained inflammation in $\mathrm{CF}$ through sustained inflammasome activation (50). Thus, restraining Th17-dependent inflammation may represent a targeted general therapy in CF $(4,51)$. However, one novel finding of this study is that replacement therapy with kynurenines also limits the effects of a deregulated inflammatory process in experimental CF. Perhaps more importantly, complete cure and reversal of the hyperinflammatory CF phenotype were achieved by administration of recombinant IFN- $\gamma$, a known IDO inducer, or supplemental kynurenines. Targeting IDO resulted in enhanced production of IL-10 and expression of Foxp3, both markers of Treg activity in Aspergillus infection and allergy (52). IL-10 production is defective in patients with CF (53) and heterogeneity in the ILIO gene may influence the response to $A$. fumigatus infection and the occurrence of $A$. fumigatus-related lung disease in patients with CF (54). IL10 gene therapy was indeed successful in dampening fungal allergy in experimental $\mathrm{CF}$, but side effects were observed on prolonged secretion of 
A
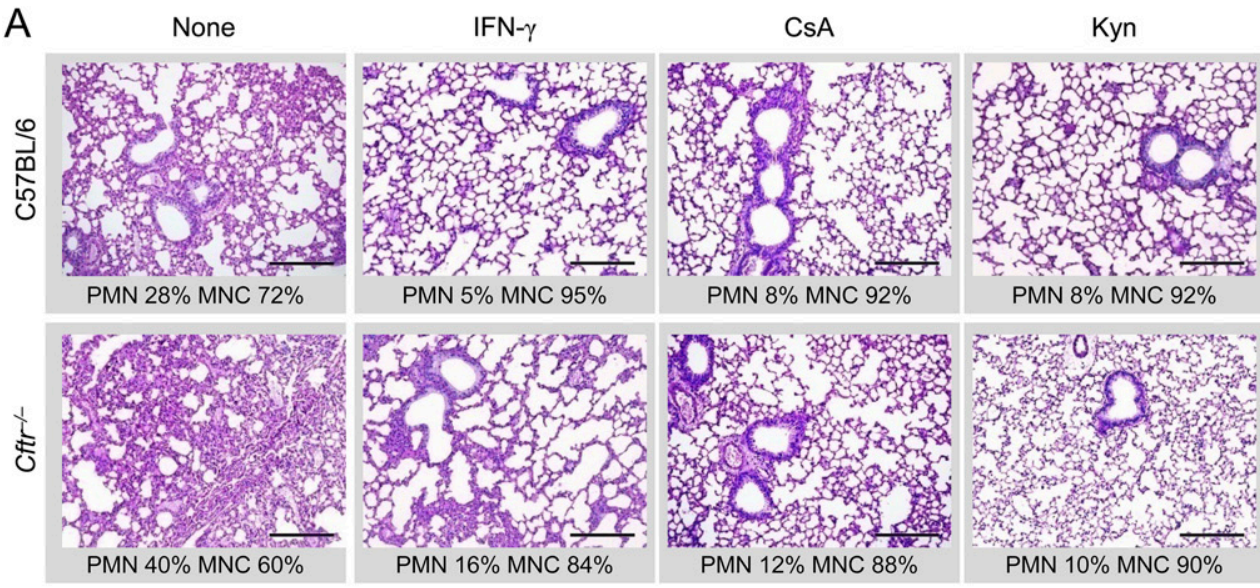

B

None
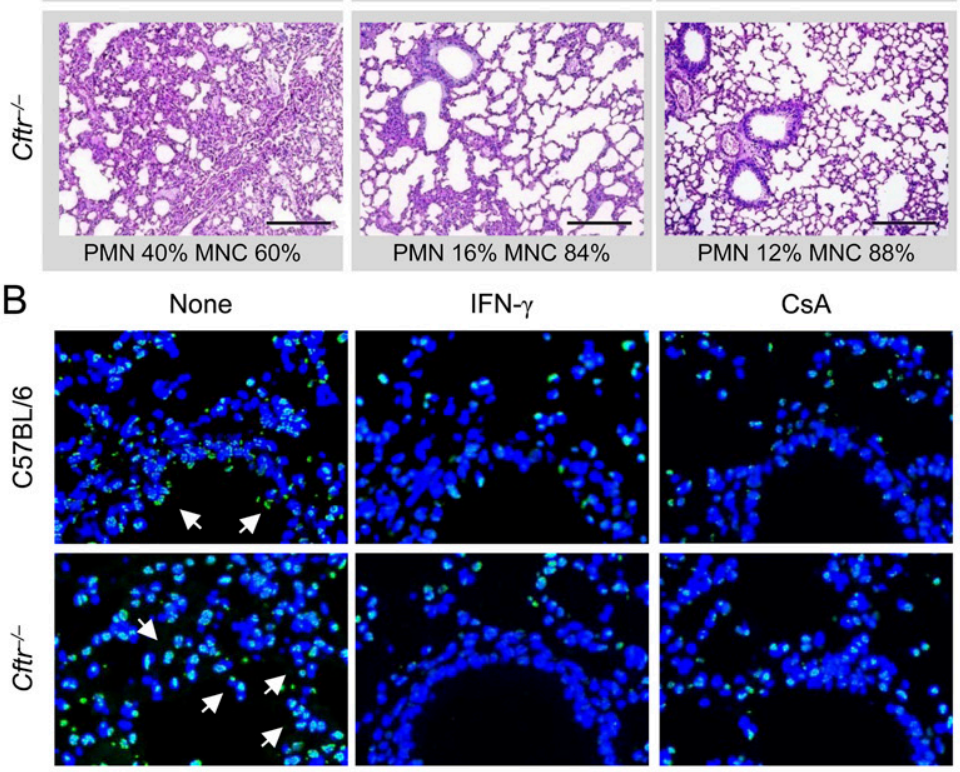

PMN $12 \%$ MNC $88 \%$

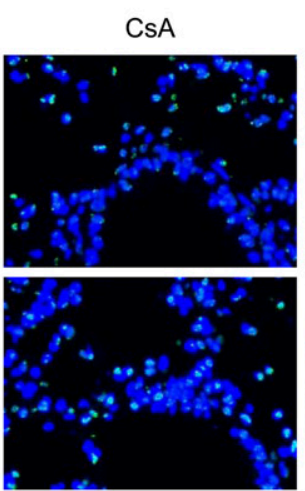

Kyn

C
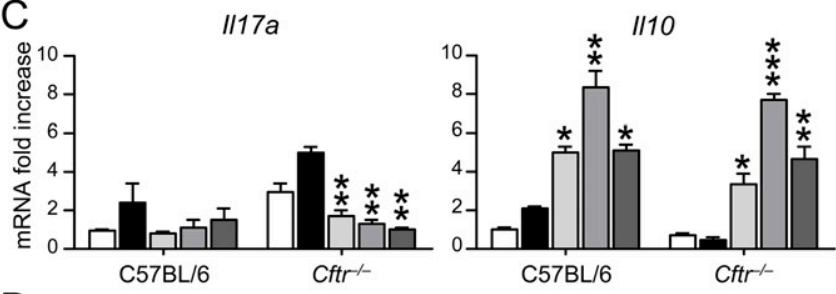

$\mathrm{C} 57 \mathrm{BL} / 6$

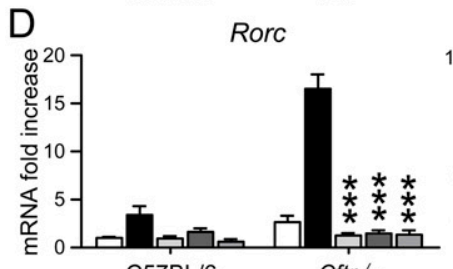

C57BL/6

$\mathrm{Cftr}^{-1}$

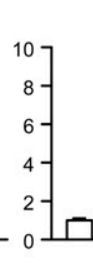

Foxp3

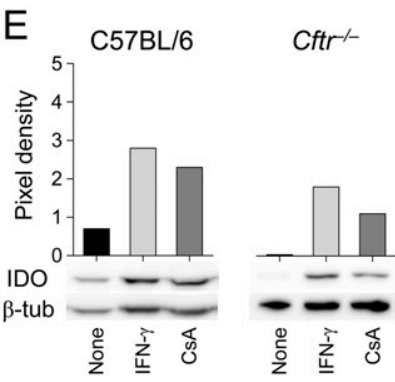

$\mathrm{F}$
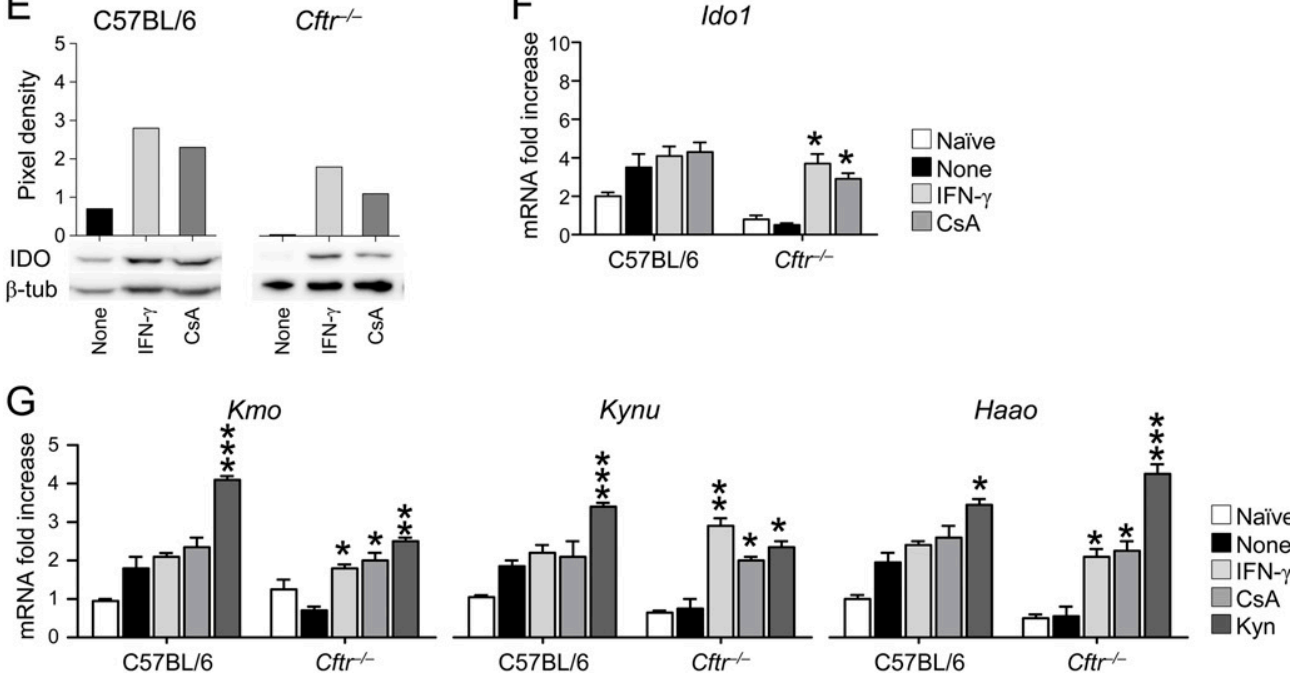

Figure 6. Restoration of indoleamine 2,3-dioxygenase (IDO) has curative effects in murine cystic fibrosis (CF). Mice (six per group) were intranasally infected with Aspergillus conidia and treated daily with IFN- $\gamma$, cyclosporine A ( $\mathrm{CsA})$, or a mixture of L-kynurenine, 3-hydroxykynurenine, and 3hydroxyanthranilic acid, starting 3 days before and up to 7 days after infection. (A) Lung histology (periodic acid-Schiff staining) and bronchoalveolar lavage morphometry (\%, mean \pm SEM, of mononuclear cells [MNC] or polymorphonuclear cells [PMN]). Photographs were taken with a high-resolution microscope (Olympus DP71) equipped with a $\times 20$ objective. Scale bars, 200 $\mu \mathrm{m}$. (B) Increased deposition of DNA on lung parenchyma cells on staining by terminal deoxynucleotidyltransferase-mediated deoxyuridine triphosphate nick-end labeling (TUNEL), resulting in bright DNA staining. Arrows, DNA deposits. Representative staining from two independent experiments is shown. The images were acquired with a fluorescence microscope equipped with a $\times 40$ objective. (C) Cytokine and $(D)$ transcription factor gene expression were assessed by RT-PCR on total lung cells or purified $\mathrm{CD}^{+} \mathrm{T}$ cells from the thoracic lymph nodes, respectively. (E) IDO protein expression (immunoblotting with rabbit polyclonal IDO-specific antibody on lung whole cell lysates) and $(F)$ Indo and $(G)$ kynurenine pathway gene expression (RT-PCR on total lung cells) in mice infected and treated as described previously. Scanning densitometry was done with Image Lab 3.1.1 software. Shown are representative Western blots of two independent experiments and corresponding pixel density ratio normalized against $\beta$-tubulin $\left(\left(\beta\right.\right.$-tub). ${ }^{*} P<$ $0.05,{ }^{* \star} P<0.01,{ }^{* * *} P<0.001$, treated versus untreated (None) mice. 
A

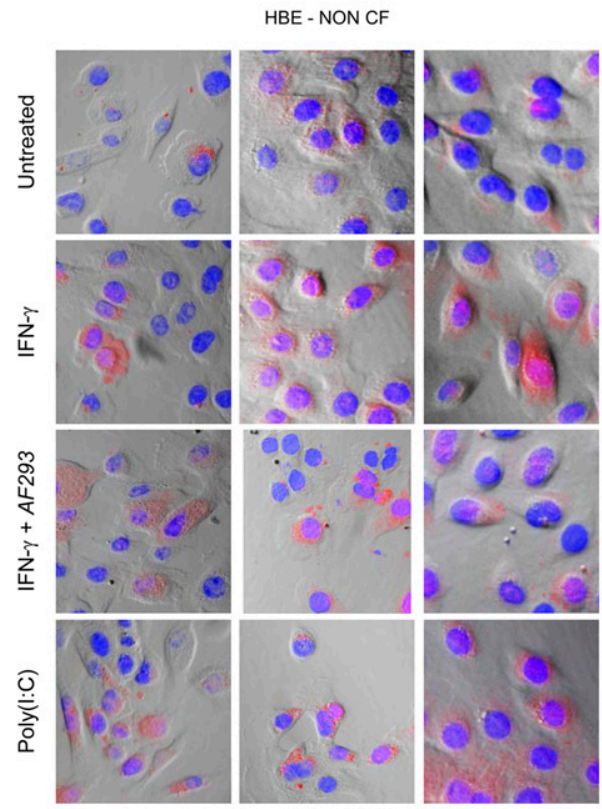

HBE- CF
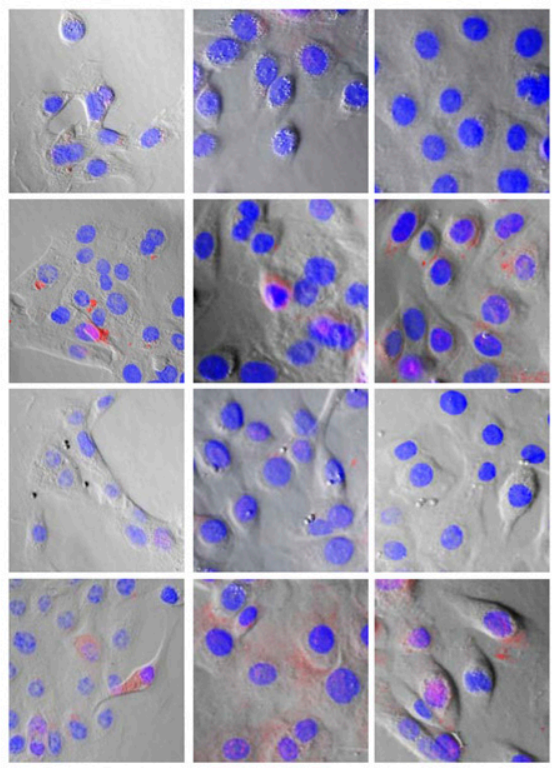

B
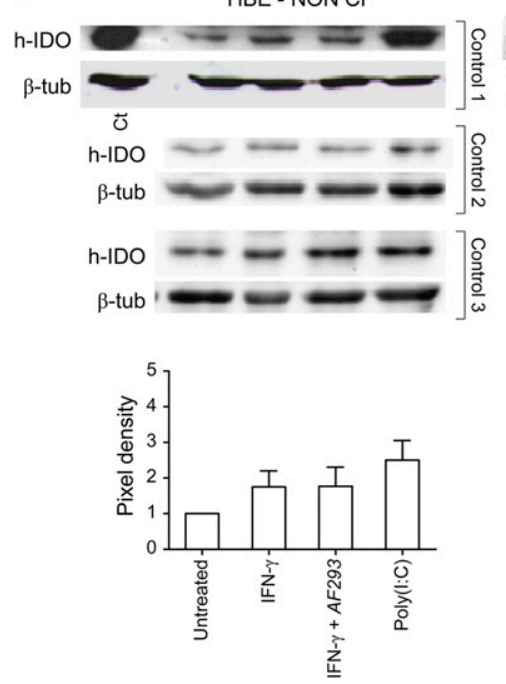
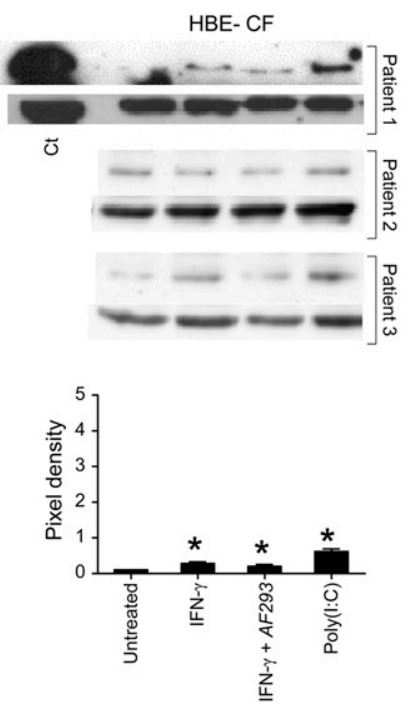

C

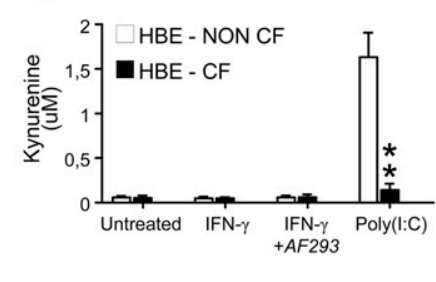

.
pixel and the corresponding pixel density ratio (mean \pm SEM of three values) normalized against $\beta$-tubulin ( $\beta$-tub). (C) Kynurenine levels (by highperformance liquid chromatography) in supernatants of $\mathrm{HBE}$ cells stimulated as described previously (mean \pm SEM of three values). ${ }^{*} P<0.05 ;{ }^{*} P<$ 0.01 , HBE-CF versus HBE-non-CF.
IL-10 (55). In contrast, the low-frequency Treg-cell population observed in CF patients with ABPA could be increased by treatment with vitamin D (36), a finding emphasizing the usefulness of targeting Tregs to prevent or treat lung pathology.

One interesting observation of the present study is the reciprocal cross-regulation between IDO and $\mathrm{Ca}^{2+}$ mobilization in DCs. On the one hand, IDO and kynurenines have been shown to impair calcium mobilization of T cells (19); on the other, we found that IDO expression in DCs is sensitive to intracellular $\mathrm{Ca}^{2+}$ levels, a finding consistent with the effects of calcineurin/ NFAT signaling on DCs (37). Thus, altered $\mathrm{Ca}^{2+}$ signaling pathways in CF cells not only contribute to T-cell dysreactivity (20) but also limit IDO functioning in tolerogenic DCs. Considering that IDO expression on epithelial cells (ECs) was similarly sensitive to intracellular $\mathrm{Ca}^{2+}$ levels (data not shown), these data further point to the critical role ECs may have in response to $A$. fumigatus in $\mathrm{CF}$ (56). The mechanisms underlying the regulation of IDO by intracellular $\mathrm{Ca}^{2+}$ signaling is presently under investigation. Preliminary observation failed to show a consensus binding sequence for NFAT on the $I D O$ promoter, a finding indicating that other components of the $\mathrm{Ca}^{2+}$ signaling pathway are involved. Irrespective of the molecular mechanism, the finding that inhibition of the $\mathrm{Ca}^{2+}$-calcineurin-NFAT signaling pathway with CsA restored IDO activity is novel and is consistent with the ability of CsA to inhibit Th17-cell activation (57) and to improve clinical signs and symptoms in patients with CF (58). As calcineurin inhibition is also known to impair virulence in $A$. fumigatus (59), these findings point to the successful manipulation of this pathway to improve outcome in CF patients with aspergillosis.

Within the priority areas identified for CF (60), the present study identifies a novel pathogenic mechanism that may contribute to $\mathrm{CF}$ lung disease, provides indications for immunogenetic screening of IDOI and kynurenine levels as biomarkers that reflect $\mathrm{CF}$ pathophysiology, and suggests new therapeutics in $\mathrm{CF}$ lung diseases. Current $\mathrm{CF}$ treatments that target respiratory infections, mucociliary clearance, and nutritional status are associated with improved pulmonary function and reduced exacerbations $(61,62)$. Within the aberrant pulmonary inflammation seen in response to the fungus in the setting of CFTR mutation, a role for antifungals to halt progressive CF lung disease has been 
suggested (56). With the exception of the first randomized controlled clinical trial showing the nonclinical benefit of itraconazole in patients with $\mathrm{CF}(63)$, there are at present no other randomized controlled trials to evaluate the use of antifungal therapies (64) or prevent resistance to antifungal therapy in people with CF $(13,65)$. Our study clearly indicates that genetic and epigenetic mechanisms collude to impair IDO activity and promote Th17-dependent inflammatory pathology in CF. Thus, the inability to properly handle respiratory fungal pathogens could be primarily responsible for the state of chronic inflammation seen in patients with $\mathrm{CF}$, and this predicts that combination strategies in CF should target primary inflammation along with pathogen eradication.

Author disclosures are available with the text of this article at www.atsjournals.org

Acknowledgment: The authors thank Dr. Dietmar Fuchs (Innsbruck Medical University, Innsbruck, Austria) for determination of the kynurenine-to-tryptophan ratios.

\section{References}

1. Ulrich M, Worlitzsch D, Viglio S, Siegmann N, Iadarola P, Shute JK, Geiser M, Pier GB, Friedel G, Barr ML, et al. Alveolar inflammation in cystic fibrosis. J Cyst Fibros 2010;9:217-227.

2. Decraene A, Willems-Widyastuti A, Kasran A, De Boeck K, Bullens DM, Dupont LJ. Elevated expression of both mRNA and protein levels of IL-17A in sputum of stable cystic fibrosis patients. Respir Res 2010;11:177.

3. McAllister F, Henry A, Kreindler JL, Dubin PJ, Ulrich L, Steele C, Finder JD, Pilewski JM, Carreno BM, Goldman SJ, et al. Role of IL-17A, IL-17F, and the IL-17 receptor in regulating growth-related oncogene- $\alpha$ and granulocyte colony-stimulating factor in bronchial epithelium: implications for airway inflammation in cystic fibrosis. $J$ Immunol 2005; 175:404-412.

4. Tan HL, Regamey N, Brown S, Bush A, Lloyd CM, Davies JC. The Th17 pathway in cystic fibrosis lung disease. Am J Respir Crit Care Med 2011;184:252-258.

5. Elizur A, Cannon CL, Ferkol TW. Airway inflammation in cystic fibrosis. Chest 2008;133:489-495.

6. Bruscia EM, Zhang PX, Ferreira E, Caputo C, Emerson JW, Tuck D, Krause DS, Egan ME. Macrophages directly contribute to the exaggerated inflammatory response in cystic fibrosis transmembrane conductance regulator $^{-1-}$ mice. Am J Respir Cell Mol Biol 2009;40:295-304.

7. Chmiel JF, Berger M, Konstan MW. The role of inflammation in the pathophysiology of CF lung disease. Clin Rev Allergy Immunol 2002; 23:5-27.

8. Klein M, Cohen-Cymberknoh M, Armoni S, Shoseyov D, Chisin R, Orevi M, Freedman N, Kerem E. ${ }^{18}$ F-fluorodeoxyglucose-PET/CT imaging of lungs in patients with cystic fibrosis. Chest 2009;136: 1220-1228.

9. Romani L, Zelante T, De Luca A, Fallarino F, Puccetti P. IL-17 and therapeutic kynurenines in pathogenic inflammation to fungi. $J$ Immunol 2008;180:5157-5162.

10. Puccetti P, Grohmann U. IDO and regulatory T cells: a role for reverse signalling and non-canonical Nf-кB activation. Nat Rev Immunol 2007; 7:817-823.

11. Romani L, Fallarino F, De Luca A, Montagnoli C, D'Angelo C, Zelante T, Vacca C, Bistoni F, Fioretti MC, Grohmann U, et al. Defective tryptophan catabolism underlies inflammation in mouse chronic granulomatous disease. Nature 2008;451:211-215.

12. Delhaes L, Monchy S, Frealle E, Hubans C, Salleron J, Leroy S, Prevotat A, Wallet F, Wallaert B, Dei-Cas E, et al. The airway microbiota in cystic fibrosis: a complex fungal and bacterial community-implications for therapeutic management. PLoS One 2012;7:e36313.

13. Knutsen AP, Bush RK, Demain JG, Denning DW, Dixit A, Fairs A, Greenberger PA, Kariuki B, Kita H, Kurup VP, et al. Fungi and allergic lower respiratory tract diseases. J Allergy Clin Immunol 2012; 129:280-291; quiz 292-283.

14. Sudfeld CR, Dasenbrook EC, Merz WG, Carroll KC, Boyle MP. Prevalence and risk factors for recovery of filamentous fungi in individuals with cystic fibrosis. J Cyst Fibros 2010;9:110-116.

15. de Vrankrijker AM, van der Ent CK, van Berkhout FT, Stellato RK, Willems RJ, Bonten MJ, Wolfs TF. Aspergillus fumigatus colonization in cystic fibrosis: implications for lung function? Clin Microbiol Infect 2011;17:1381-1386.

16. Stevens DA, Moss RB, Kurup VP, Knutsen AP, Greenberger P, Judson MA, Denning DW, Crameri R, Brody AS, Light M, et al. Allergic bronchopulmonary aspergillosis in cystic fibrosis-state of the art: Cystic Fibrosis Foundation consensus conference. Clin Infect Dis 2003;37(Suppl 3):S225-S264.

17. Mastella G, Rainisio M, Harms HK, Hodson ME, Koch C, Navarro J, Strandvik B, McKenzie SG. Allergic bronchopulmonary aspergillosis in cystic fibrosis. Eur Respir J 2001;17:1052-1053.

18. Palmer LB, Greenberg HE, Schiff MJ. Corticosteroid treatment as a risk factor for invasive aspergillosis in patients with lung disease. Thorax 1991;46:15-20.

19. Iken K, Liu K, Liu H, Bizargity P, Wang L, Hancock WW, Visner GA. IDO and metabolites protect mouse lung allografts and impair calcium mobilization of T cells. Am J Respir Cell Mol Biol 2012;47:405-416.

20. Antigny F, Norez C, Becq F, Vandebrouck C. Calcium homeostasis is abnormal in cystic fibrosis airway epithelial cells but is normalized after rescue of F508del-CFTR. Cell Calcium 2008;43:175-183.

21. Bragonzi A. Murine models of acute and chronic lung infection with cystic fibrosis pathogens. Int J Med Microbiol 2010;300:584-593.

22. Iannitti RG, Carvalho A, De Luca A, Giovannini G, Casagrande A, Cunha C, De Benedictis FM, Romani L. Cystic fibrosis Th17/Treg imbalance to Aspergillus fumigatus: insights for novel anti-inflammatory strategies and immunogenetic screening [abstract]. In: Chernick V, editor. The 26th Annual North American Cystic Fibrosis Conference. Pediatr Pulmonol 2012;47:338.

23. Zhou L, Dey CR, Wert SE, DuVall MD, Frizzell RA, Whitsett JA. Correction of lethal intestinal defect in a mouse model of cystic fibrosis by human CFTR. Science 1994;266:1705-1708.

24. Bonifazi P, Zelante T, D'Angelo C, De Luca A, Moretti S, Bozza S, Perruccio K, Iannitti RG, Giovannini G, Volpi C, et al. Balancing inflammation and tolerance in vivo through dendritic cells by the commensal Candida albicans. Mucosal Immunol 2009;2:362-374.

25. Montagnoli C, Fallarino F, Gaziano R, Bozza S, Bellocchio S, Zelante T, Kurup WP, Pitzurra L, Puccetti P, Romani L. Immunity and tolerance to Aspergillus involve functionally distinct regulatory $\mathrm{T}$ cells and tryptophan catabolism. J Immunol 2006;176:1712-1723.

26. Galietta LJ, Folli C, Marchetti C, Romano L, Carpani D, Conese M, Zegarra-Moran O. Modification of transepithelial ion transport in human cultured bronchial epithelial cells by interferon- $\gamma$. Am J Physiol Lung Cell Mol Physiol 2000;278:L1186-L1194.

27. de Luca A, Bozza S, Zelante T, Zagarella S, D'Angelo C, Perruccio K, Vacca C, Carvalho A, Cunha C, Aversa F, et al. Non-hematopoietic cells contribute to protective tolerance to Aspergillus fumigatus via a TRIF pathway converging on IDO. Cell Mol Immunol 2010;7:459-470.

28. Schrocksnadel K, Wirleitner B, Winkler C, Fuchs D. Monitoring tryptophan metabolism in chronic immune activation. Clin Chim Acta 2006;364:82-90.

29. Di A, Brown ME, Deriy LV, Li C, Szeto FL, Chen Y, Huang P, Tong J, Naren AP, Bindokas V, et al. CFTR regulates phagosome acidification in macrophages and alters bactericidal activity. Nat Cell Biol 2006;8:933-944.

30. Gessner MA, Werner JL, Lilly LM, Nelson MP, Metz AE, Dunaway CW, Chan YR, Ouyang W, Brown GD, Weaver CT, et al. Dectin-1dependent interleukin-22 contributes to early innate lung defense against Aspergillus fumigatus. Infect Immun 2012;80:410-417.

31. Chan YR, Chen K, Duncan SR, Lathrop KL, Latoche JD, Logar AJ, Pociask DA, Wahlberg BJ, Ray P, Ray A, et al. Patients with cystic fibrosis have inducible $\mathrm{IL}-17^{+} \mathrm{IL}-22^{+}$memory cells in lung draining lymph nodes. J Allergy Clin Immunol (In press)

32. Qiu J, Heller JJ, Guo X, Chen ZM, Fish K, Fu YX, Zhou L. The aryl hydrocarbon receptor regulates gut immunity through modulation of innate lymphoid cells. Immunity 2012;36:92-104.

33. Romani L. Immunity to fungal infections. Nat Rev Immunol 2011;11:275-288.

34. Allard JB, Poynter ME, Marr KA, Cohn L, Rincon M, Whittaker LA. Aspergillus fumigatus generates an enhanced Th2-biased immune response in mice with defective cystic fibrosis transmembrane conductance regulator. J Immunol 2006;177:5186-5194.

35. Mueller C, Braag SA, Keeler A, Hodges C, Drumm M, Flotte TR. Lack of cystic fibrosis transmembrane conductance regulator in $\mathrm{CD}^{+}$lymphocytes leads to aberrant cytokine secretion and hyperinflammatory adaptive immune responses. Am J Respir Cell Mol Biol 2011;44:922-929. 
36. Kreindler JL, Steele C, Nguyen N, Chan YR, Pilewski JM, Alcorn JF, Vyas YM, Aujla SJ, Finelli P, Blanchard M, et al. Vitamin $\mathrm{D}_{3}$ attenuates Th2 responses to Aspergillus fumigatus mounted by $\mathrm{CD}^{+}{ }^{+} \mathrm{T}$ cells from cystic fibrosis patients with allergic bronchopulmonary aspergillosis. J Clin Invest 2010;120:3242-3254.

37. Fric J, Lim CX, Koh EG, Hofmann B, Chen J, Tay HS, Mohammad Isa SA, Mortellaro A, Ruedl C, Ricciardi-Castagnoli P. Calcineurin/ NFAT signalling inhibits myeloid haematopoiesis. EMBO Mol Med 2012;4:269-282.

38. Grohmann U, Fallarino F, Bianchi R, Orabona C, Vacca C, Fioretti MC, Puccetti P. A defect in tryptophan catabolism impairs tolerance in nonobese diabetic mice. J Exp Med 2003;198:153-160.

39. Chmiel JF, Konstan MW. Anti-inflammatory medications for cystic fibrosis lung disease: selecting the most appropriate agent. Treat Respir Med 2005;4:255-273.

40. de Benedictis FM, Bush A. Corticosteroids in respiratory diseases in children. Am J Respir Crit Care Med 2012;185:12-23.

41. Jubin V, Ranque S, Stremler Le Bel N, Sarles J, Dubus JC. Risk factors for Aspergillus colonization and allergic bronchopulmonary aspergillosis in children with cystic fibrosis. Pediatr Pulmonol 2010;45:764-771.

42. Pressler T. Targeting airway inflammation in cystic fibrosis in children: past, present, and future. Paediatr Drugs 2011;13:141-147.

43. Knutsen AP, Slavin RG. Allergic bronchopulmonary aspergillosis in asthma and cystic fibrosis. Clin Dev Immunol 2011;2011:843763.

44. Carvalho A, Pasqualotto AC, Pitzurra L, Romani L, Denning DW, Rodrigues F. Polymorphisms in Toll-like receptor genes and susceptibility to pulmonary aspergillosis. J Infect Dis 2008;197:618-621.

45. Guilbault C, Wojewodka G, Saeed Z, Hajduch M, Matouk E, De Sanctis JB, Radzioch D. Cystic fibrosis fatty acid imbalance is linked to ceramide deficiency and corrected by fenretinide. Am J Respir Cell Mol Biol 2009; 41:100-106.

46. Gammelsrud KW, Sandven P, Hoiby EA, Sandvik L, Brandtzaeg P, Gaustad P. Colonization by Candida in children with cancer, children with cystic fibrosis, and healthy controls. Clin Microbiol Infect 2011; 17:1875-1881.

47. Zelante T, De Luca A, Bonifazi P, Montagnoli C, Bozza S, Moretti S, Belladonna ML, Vacca C, Conte C, Mosci P, et al. IL-23 and the Th17 pathway promote inflammation and impair antifungal immune resistance. Eur J Immunol 2007;37:2695-2706.

48. Zelante T, Iannitti RG, De Luca A, Arroyo J, Blanco N, Servillo G, Sanglard D, Reichard U, Palmer GE, Latge JP, et al. Sensing of mammalian IL-17A regulates fungal adaptation and virulence. Nat Commun 2012;3:683.

49. Roussel L, Rousseau S. IL-17 primes airway epithelial cells lacking functional cystic fibrosis transmembrane conductance regulator (CFTR) to increase NOD1 responses. Biochem Biophys Res Commun 2010;391: 505-509.

50. Tang A, Sharma A, Jen R, Hirschfeld AF, Chilvers MA, Lavoie PM, Turvey SE. Inflammasome-mediated IL-1 $\beta$ production in humans with cystic fibrosis. PLoS One 2012;7:e37689.

51. Dubin PJ, Kolls JK. IL-17 in cystic fibrosis: more than just Th17 cells. Am J Respir Crit Care Med 2011;184:155-157.
52. Grohmann U, Volpi C, Fallarino F, Bozza S, Bianchi R, Vacca C, Orabona C, Belladonna ML, Ayroldi E, Nocentini G, et al. Reverse signaling through GITR ligand enables dexamethasone to activate IDO in allergy. Nat Med 2007;13:579-586.

53. Casaulta C, Schoni MH, Weichel M, Crameri R, Jutel M, Daigle I, Akdis M, Blaser K, Akdis CA. IL-10 controls Aspergillus fumigatus- and Pseudomonas aeruginosa-specific T-cell response in cystic fibrosis. Pediatr Res 2003;53:313-319.

54. Brouard J, Knauer N, Boelle PY, Corvol H, Henrion-Caude A, Flamant C, Bremont F, Delaisi B, Duhamel JF, Marguet C, et al. Influence of interleukin-10 on Aspergillus fumigatus infection in patients with cystic fibrosis. J Infect Dis 2005;191:1988-1991.

55. Mueller C, Braag SA, Martino AT, Tang Q, Campbell-Thompson M, Flotte TR. The pros and cons of immunomodulatory IL-10 gene therapy with recombinant $\mathrm{AAV}$ in a $\mathrm{Cftr}^{-1-}$-dependent allergy mouse model. Gene Ther 2009;16:172-183.

56. Chaudhary N, Datta K, Askin FB, Staab JF, Marr KA. Cystic fibrosis transmembrane conductance regulator regulates epithelial cell response to Aspergillus and resultant pulmonary inflammation. Am J Respir Crit Care Med 2012;185:301-310.

57. Tsuda K, Yamanaka K, Kitagawa H, Akeda T, Naka M, Niwa K, Nakanishi T, Kakeda M, Gabazza EC, Mizutani H. Calcineurin inhibitors suppress cytokine production from memory $\mathrm{T}$ cells and differentiation of naive $\mathrm{T}$ cells into cytokine-producing mature T cells. PLoS One 2012;7:e31465.

58. Tesse R, Manca A, Abrusci MR, Pinto S, Leonetti G, De Robertis S, Cavallo L, De Robertis F. The role of post-transplantation cyclosporine treatment in the course of cystic fibrosis pulmonary disease: a case report. Immunopharmacol Immunotoxicol 2012;34:714-716.

59. Steinbach WJ, Reedy JL, Cramer RA Jr, Perfect JR, Heitman J. Harnessing calcineurin as a novel anti-infective agent against invasive fungal infections. Nat Rev Microbiol 2007;5:418-430.

60. Ramsey BW, Banks-Schlegel S, Accurso FJ, Boucher RC, Cutting GR, Engelhardt JF, Guggino WB, Karp CL, Knowles MR, Kolls JK, et al. Future directions in early cystic fibrosis lung disease research. Am J Respir Crit Care Med 2012;185:887-892.

61. Cohen-Cymberknoh M, Shoseyov D, Kerem E. Managing cystic fibrosis: strategies that increase life expectancy and improve quality of life. Am J Respir Crit Care Med 2011;183:1463-1471.

62. Pier GB. The challenges and promises of new therapies for cystic fibrosis. J Exp Med 2012;209:1235-1239.

63. Aaron SD, Vandemheen KL, Freitag A, Pedder L, Cameron W, Lavoie A, Paterson N, Wilcox P, Rabin H, Tullis E, et al. Treatment of Aspergillus fumigatus in patients with cystic fibrosis: a randomized, placebo-controlled pilot study. PLoS One 2012;7:e36077.

64. Elphick HE, Southern KW. Antifungal therapies for allergic bronchopulmonary aspergillosis in people with cystic fibrosis. Cochrane Database Syst Rev 2012;6:CD002204.

65. Amorim A, Guedes-Vaz L, Araujo R. Susceptibility to five antifungals of Aspergillus fumigatus strains isolated from chronically colonised cystic fibrosis patients receiving azole therapy. Int J Antimicrob Agents 2010;35:396-399. 